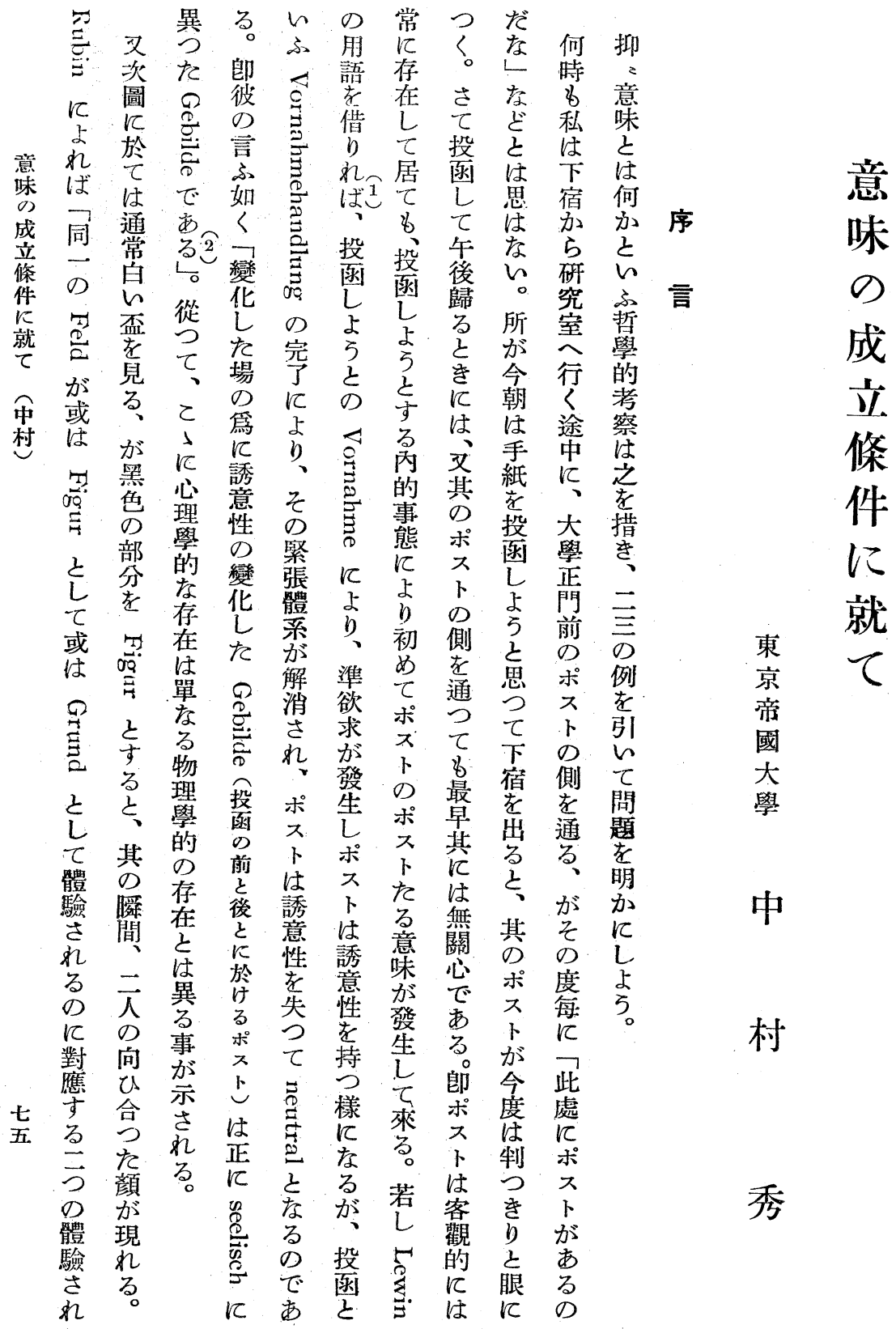




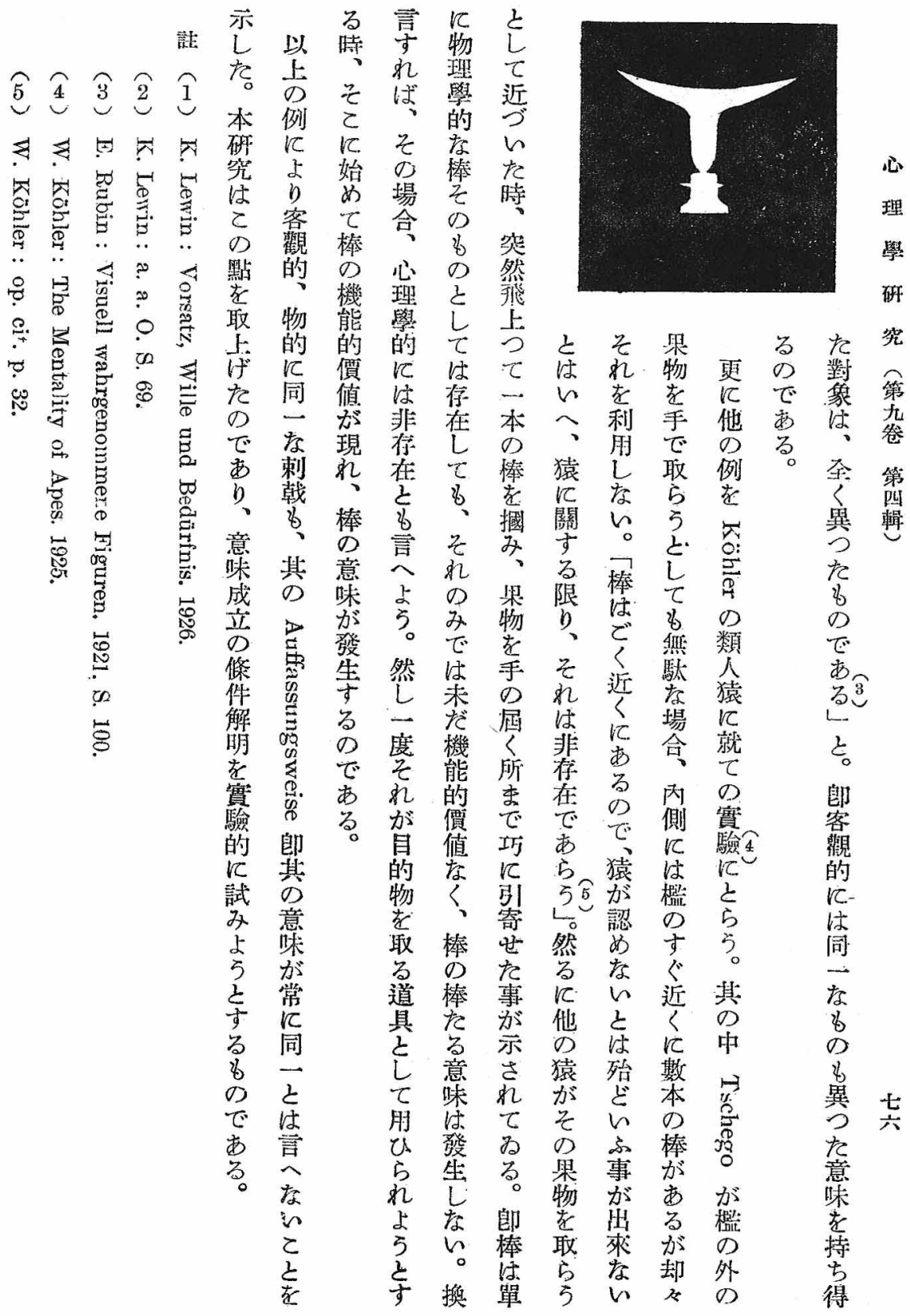




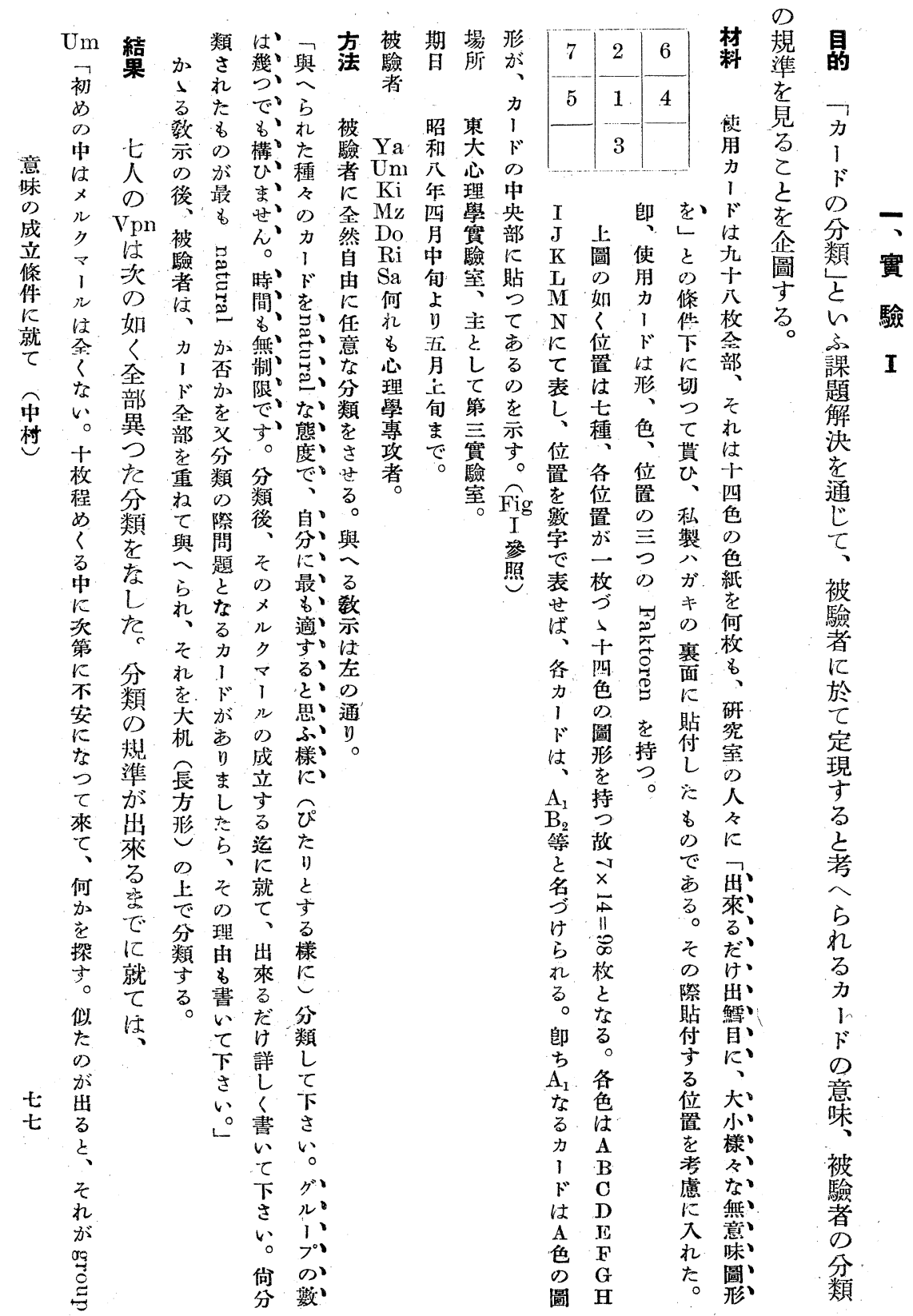


Fig. I a

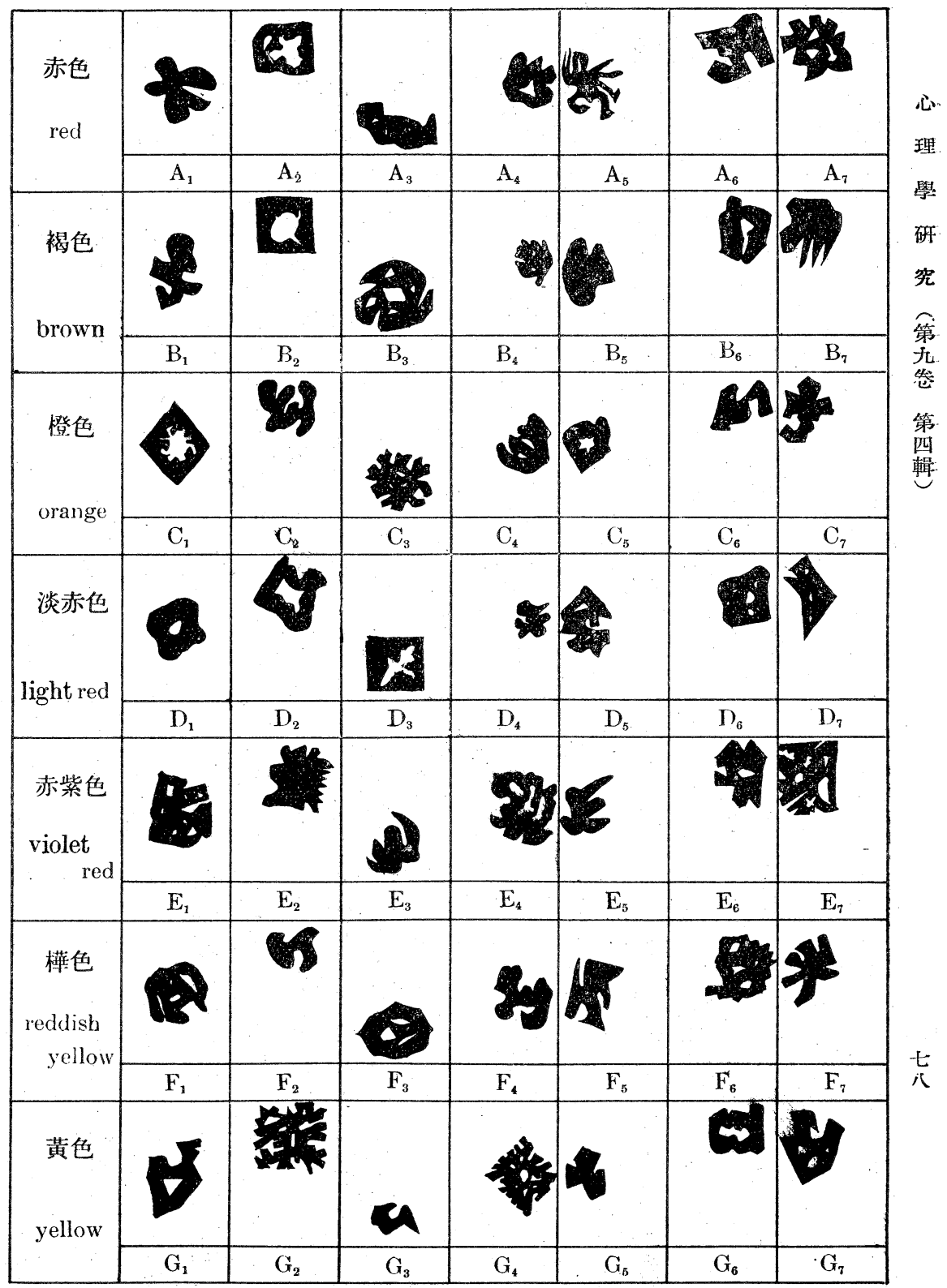


Fig. I b

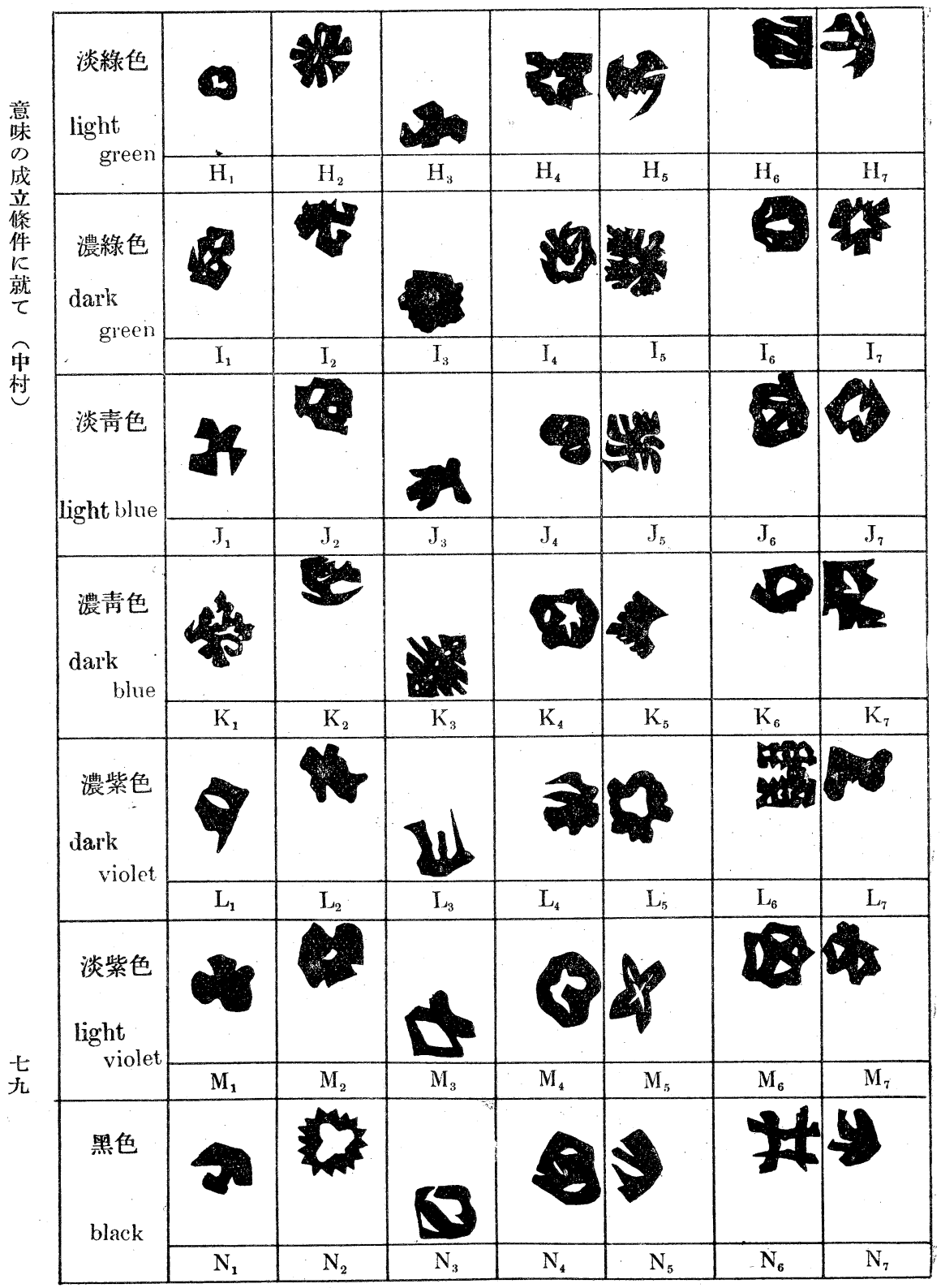




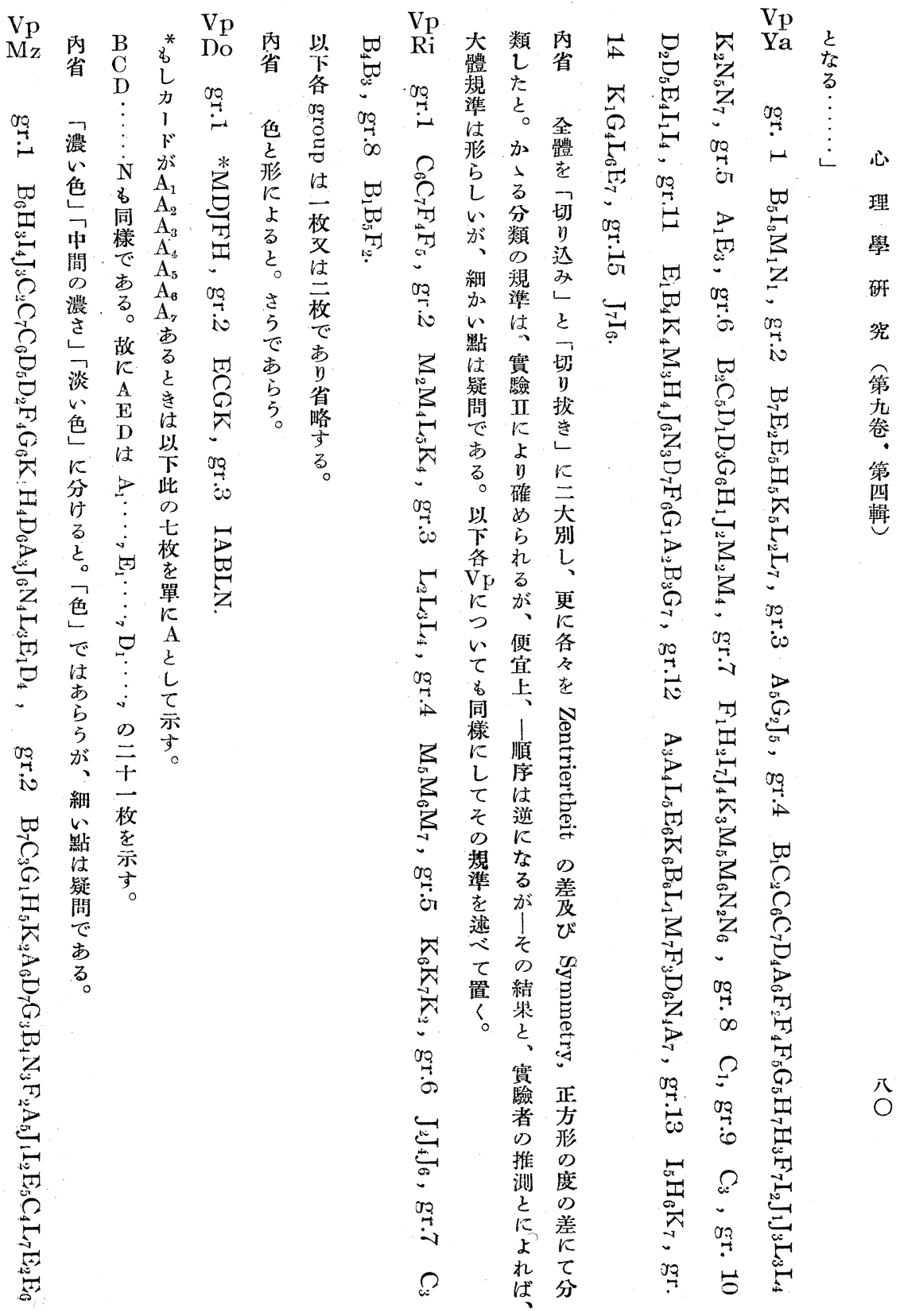




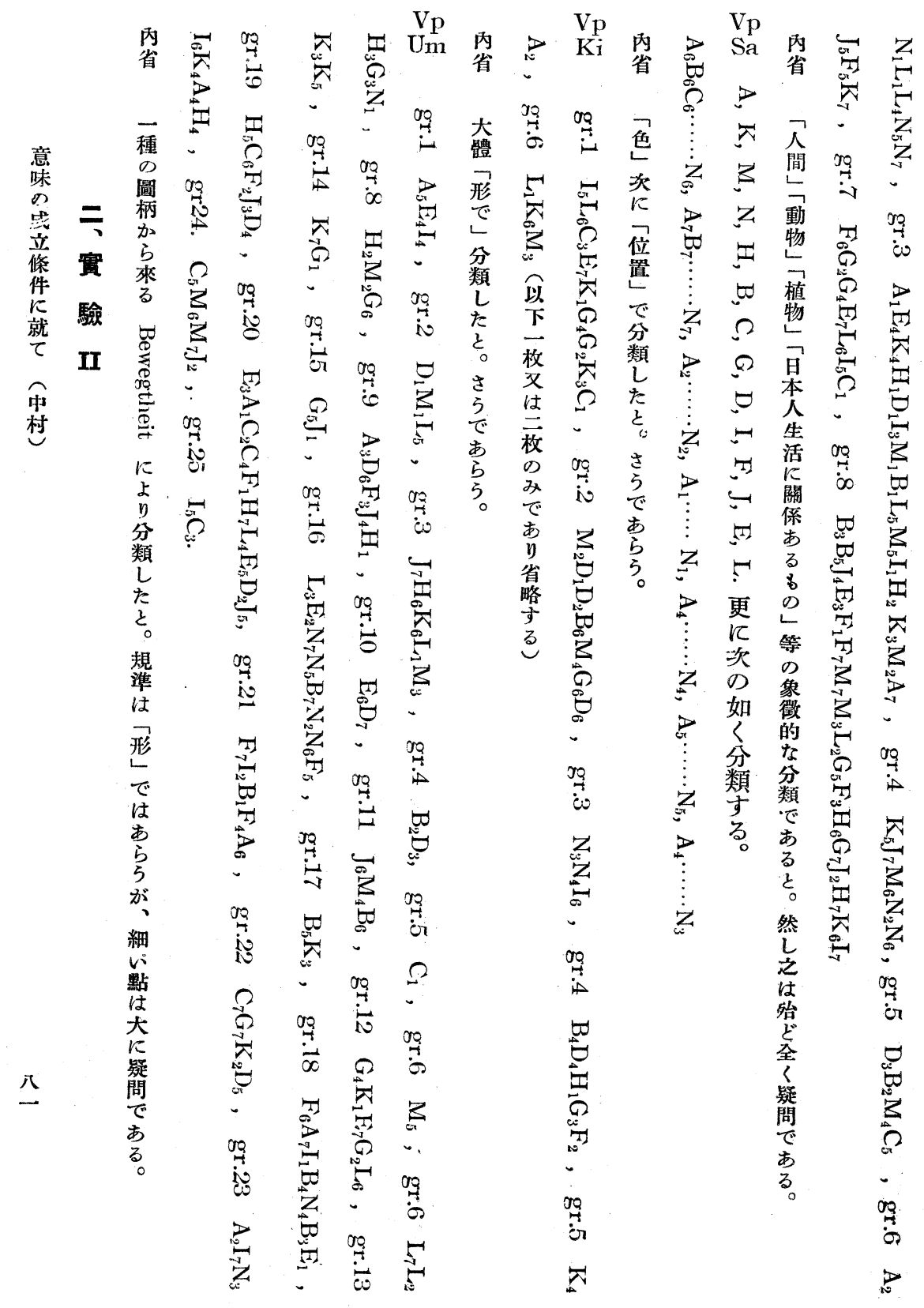




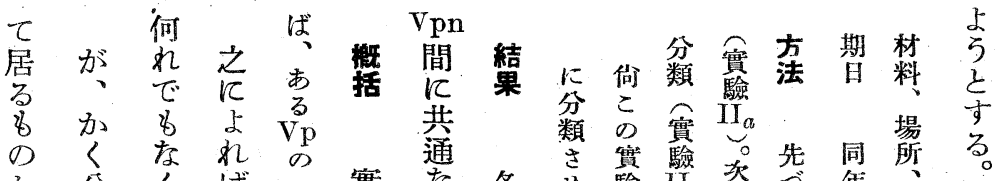

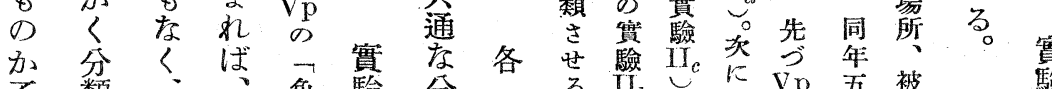

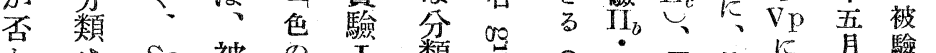

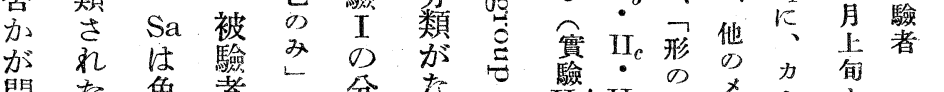

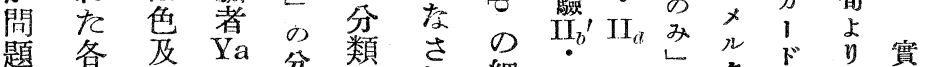

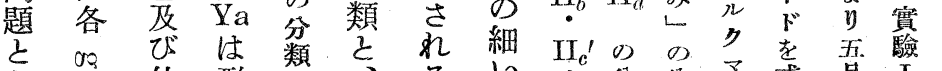

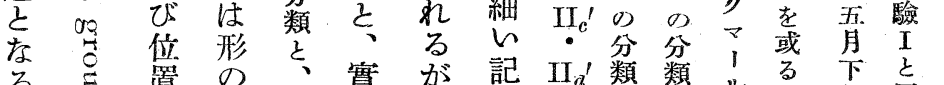
る。置 の 若、は、

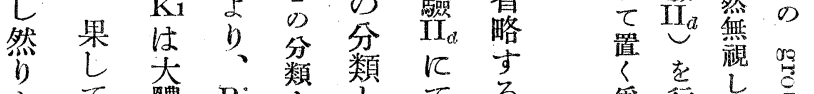

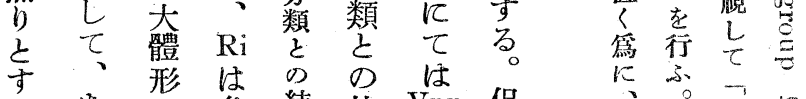
れちで色結此 Vpn 但各此色に ばや、攵果較がし、各紫包分

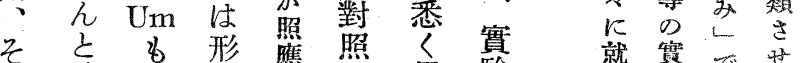

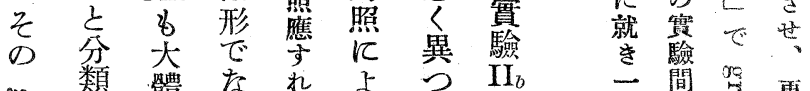

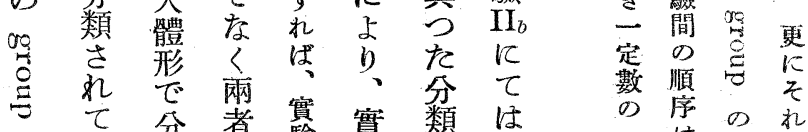
の、分者實實類は は 意 一

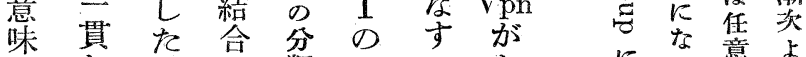
がしらに類分のの台、意占

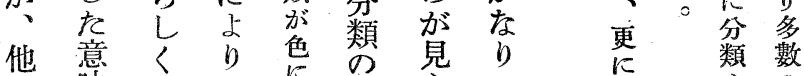

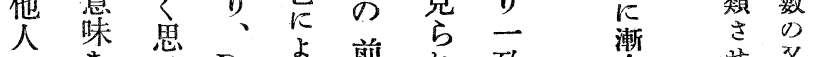

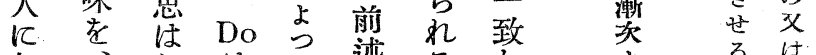
郎、机はた 述る。し

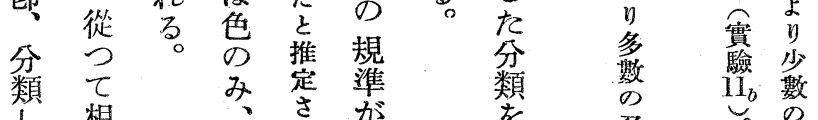

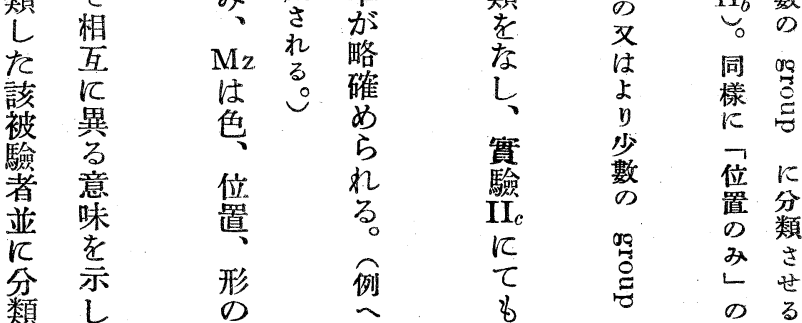




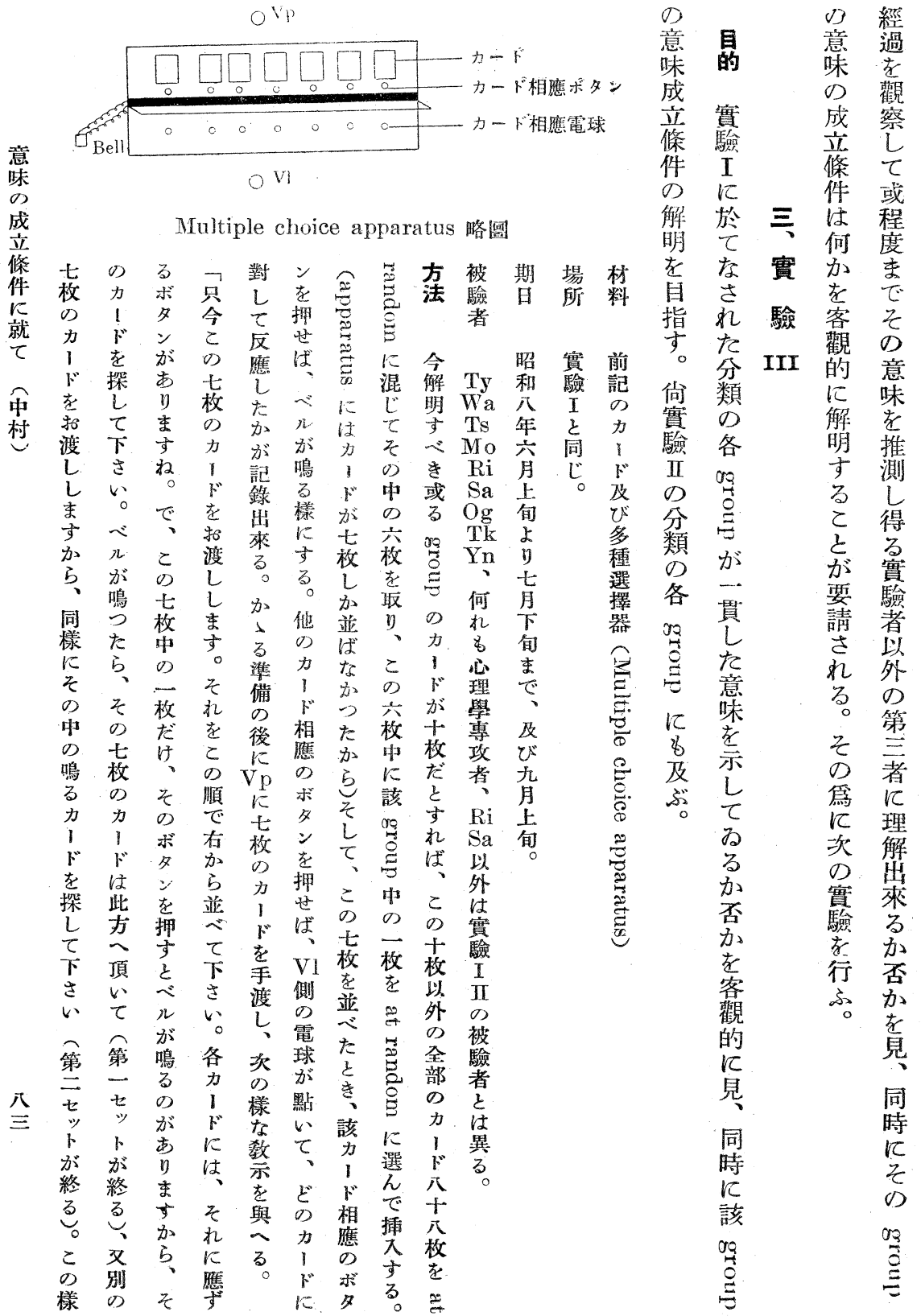




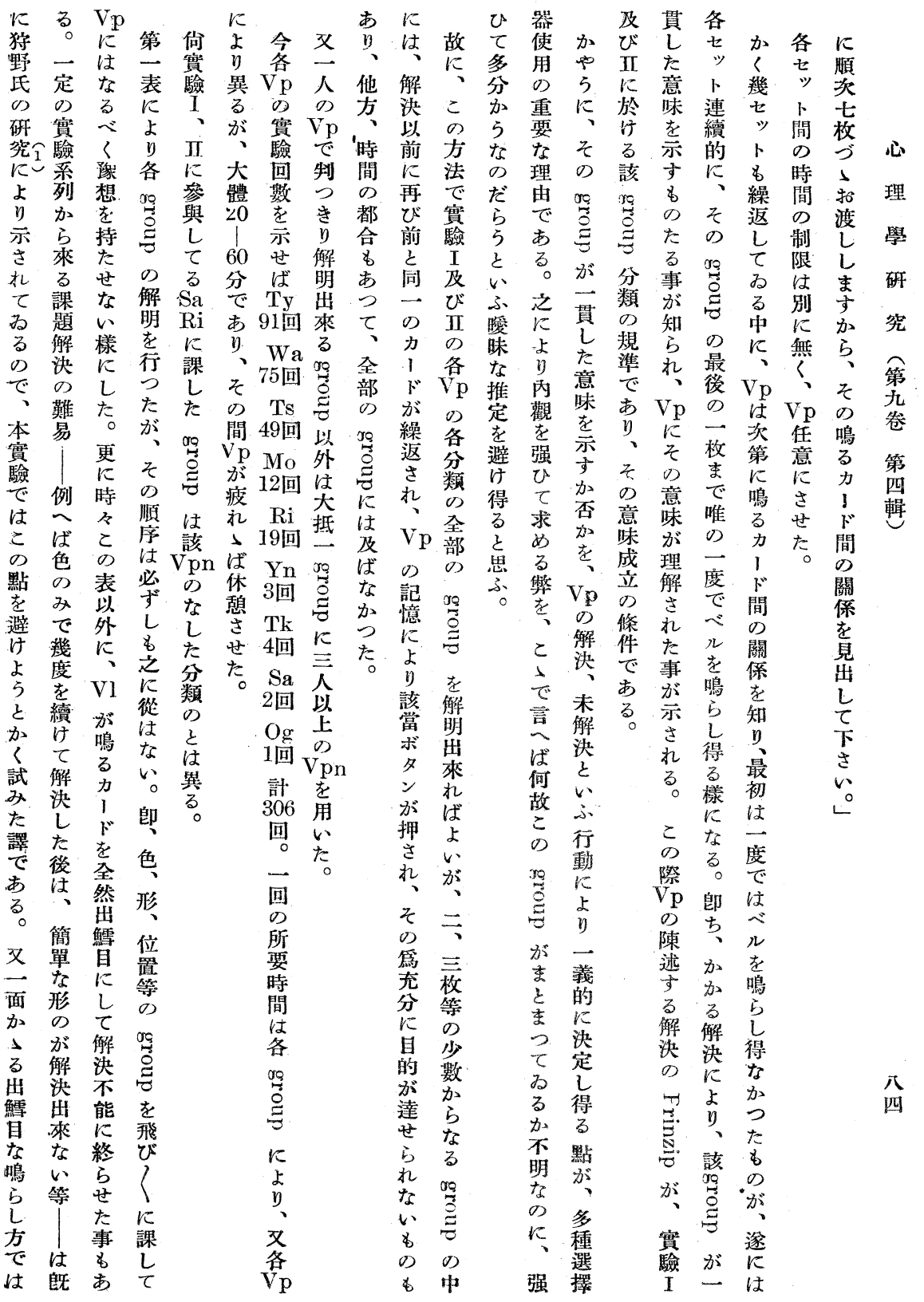


䝿驗 I

第 一 表

$\begin{array}{llllllllllll}\text { Vp. Ya gr. } 1 & 4 \text { 枚 } & \text { gr. } 2 & 7 \text { 枚 } & \text { gr. } 3 & 3 \text { 枚 } & \text { gr. } 4 & 23 \text { 枚 } & \text { gr. } 6 & 9 \text { 枚 }\end{array}$

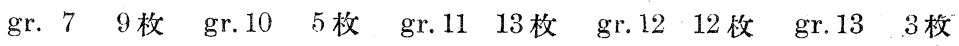
gr. 144 枚

Vp. Ri gr. 1 4 枚 gr. 2. 4 枚 $\operatorname{gr} .3$ 3枚

Vp. Ki gr. 19 枚 $\quad$ gr. 247 枚 $\quad$ gr. 4 5 枚

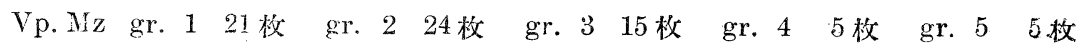
yr. 64 枚 $\mathrm{gr} .7 \quad 7$ 枚 $\mathrm{gr} .8 \quad 17$ 枚

Vp. Do gr. 1 35 枚 $\mathrm{gr} .228$ 枚 $\quad$ gr. 338 枚

Vp. Sa gr. 1-gr.14 各7枚 gr. 1-gr. 7 各 14 枚

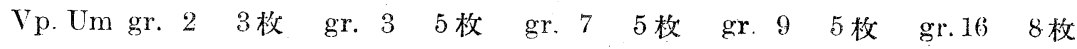

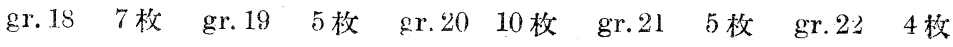
gr. 2:3 7 枚 gr.24 4 枚

實驗 $\Pi b$

Vp. Ya A, B, C, D, E, F, G, H, I, J, K, L, M, N

Vp. $\mathrm{Nz}$ AED, HI, JK, LM, BCF

實驗 $\pi \mathrm{b}^{\prime}$

Vp. Ya CF, HI, LM, ED (以」: 10 分数) BCF, EDLM (8 分類) ABCF, HIJ, KEDLM ( 5 分類)

Vp. Um JK ( 7 分類) JKLMHIG, AEDBCF ( 3 分類)

Vp. Ki AED, GHI ( 7 分類) BCFAEDJKLM ( 2 分類)

Vp.Sa GN, HIADJK, BCFLME ( 3 分類) NL, GF, BC, AD, EM ( 7 分類)

Vp. M\% LMHIJKN ( 3 分類) LME ( 7 分類)

Vp. Do BF ( 10 分類) LIK, MJD, HCF, ABEG (5 分類) NJKLMID, AEGHBCF ( 2 分類)

Vp. Ri BN, AE, DG ( 7 分類) 
實驗 IIC

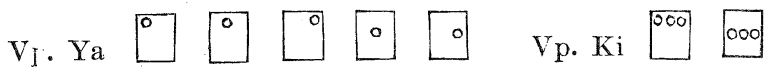

實驗 $I I c^{\prime}$

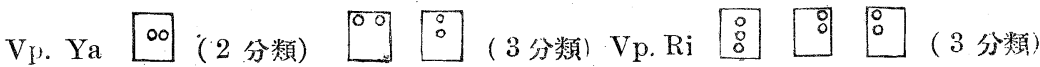

Vp. Do 8 (2 分類) Vp. Ki 00 (3 分類)

實驗 $\pi d$

Vp.Sa gr. 1 13枚 gr. 2 S枚 $\quad$ gr. 320 枚 $\quad$ gr. 4 14枚 $\quad$ gr. 5 20枚 $\begin{array}{llllll}\text { gr. } 6 & 8 \text { 枚 } & \text { gr. } 7 & \text { 巳 枚 } & \text { gr. } 8 & 4 \text { 枚 }\end{array}$

Vp. Do gr. 1 41 枚 gr. 2 25 枚 gr. 3 32枚

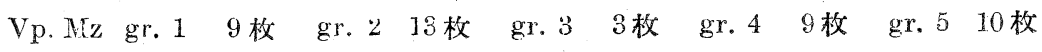
gr。 6 42 枚 gr. 7 1. 枚

實驗 $I I d^{\prime}$

Vp.Sa gr. $3^{\prime} 11$ 枚 $\mathrm{gr} .3^{\prime \prime} 9$ 枚 (10 分類) gr. 3 46 枚 $\mathrm{gr} .424$ 枚 ( 4 分類)

實驗 II a

Vp. Ri NJKLM ( 3 分類) NJK ( 5 分類)

Vp. Do AEDBCFG ( 2 分類) CEH, AKLI, JFIM, BG（5 分類）

Vp. Um gr. 117 枚 $\quad$ gr.2 16 枚 $\quad$ gr. 3 51枚 $\quad$ gr. 4 14 枚 (4 分類)

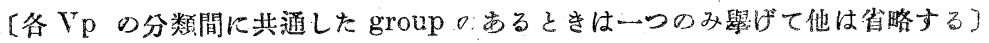




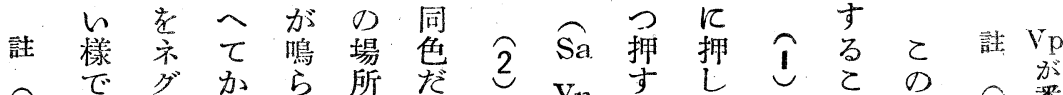

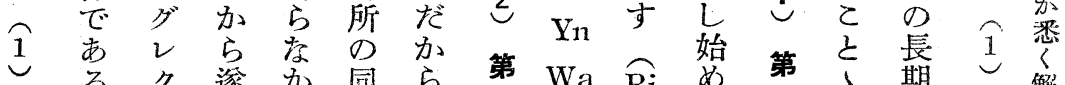

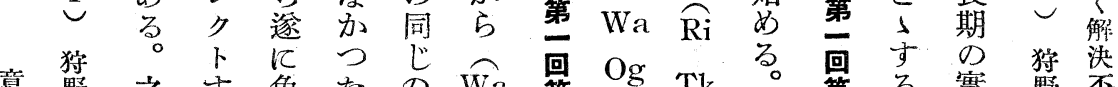

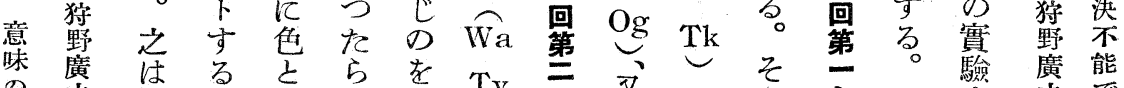

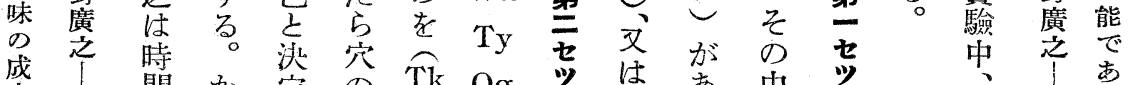

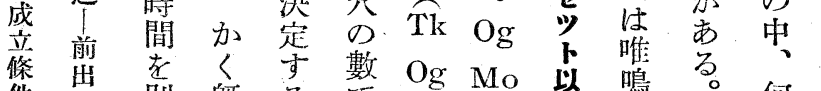

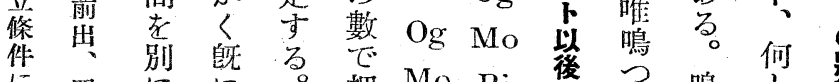

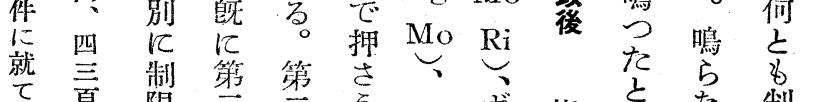

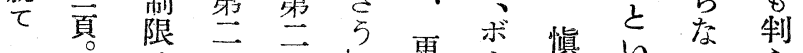
丹某 せ 村 第 で だ 考敗

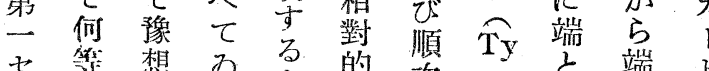

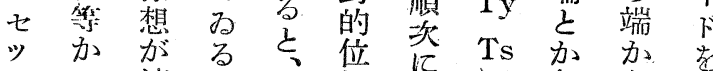

○の適。前押 置 ら渡

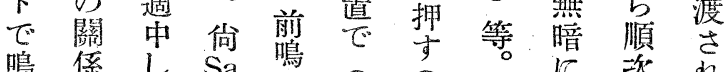
て 求索他 た か め ま 色 等 Sa

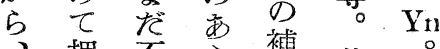
力势安安色此他 10 号 $\overparen{O g}$ 際は ドで、可 孝要佮能专功方

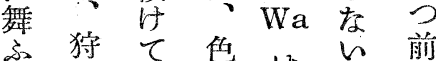
ま 野鳴色は鹪 で 氏 る 形第他店 にのを・二のつ 餘口漸 位セ關た 裕衝次置 仯力 が動確・卜老!

八あ的信音考考

五る行年夕押人之 甥出ン卞て 似 b年来の 前押た ではて 順に方充 离見他序方等

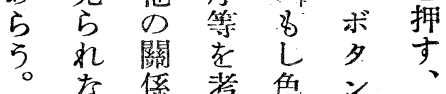
他押市 老凝 押 方 寸。 $\widehat{\mathrm{Ty}}$ 㟀 鳴 Wa 考 $\begin{array}{lll}? & \text { Ts } & \tau \\ \tau & \text { Yn } t\end{array}$ 另 Yn 枚 占 Mo 考

そ Og 味 カ又る

ははの

ド何は

ので 唯 特 8 徵文人 卖 く 手 吟近他先 味の秚報 な係考色ン、方—古

$\mathrm{V}_{\mathrm{p}}$ 愽呄 の 的 行方 動法 解 㜈よ決 想意さ の昧た 變主吅 华㽪: 考 に 研は 就 究 貫 は 本し 面誌た 白第意 几 四紫 事 第 持 貫第つ が 輯て 出䊏 た

來 三事 乙 童 万 面證 ○ 具明

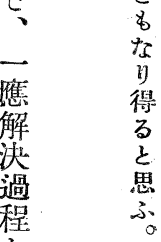
加 方 先 告 


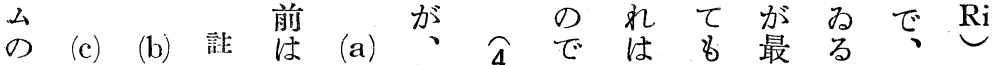

順 ○左、解 4 あ 同 8 が前又

出 色 位 1 置 方

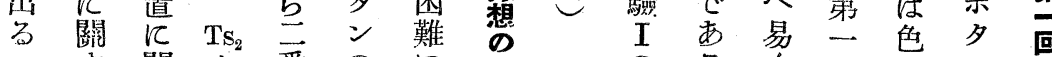

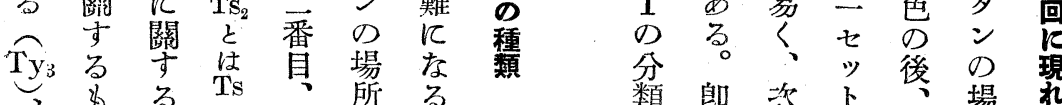

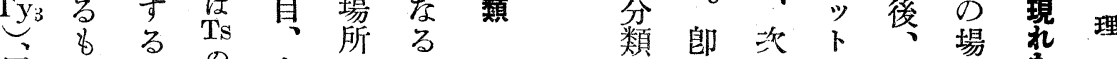

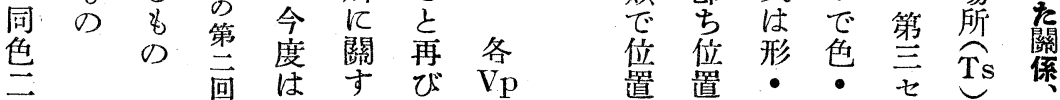

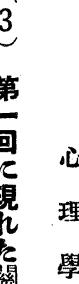

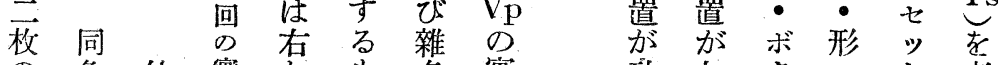

の色 位惯加8 多實殆 如夕・卜考

中它置驗らの驗息何ンボでへ

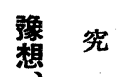

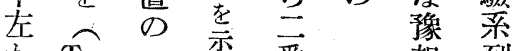

加 $T_{s_{1}}$ 示 番 想 列

右 對。自同㤎起

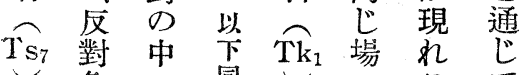

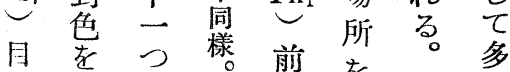

立 が塑古

色 $\mathrm{Og}_{1}$ を 方 $\overparen{\mathrm{Ts}}$

色、 る 鳴 $\underbrace{}_{2}$ 豫

前 ら 想

瓜 $\mathrm{Wa}_{1}$ 泉順

$\mathrm{Ri}_{4} \supset \mho_{0}$ 次 現

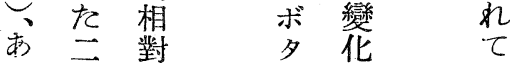

る 色 的 ン 寸

色の 位 学

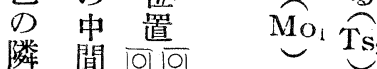

隣

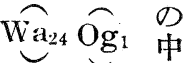

等:

闃学

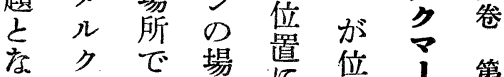

ら マ あ 所 昜 置 ル 第

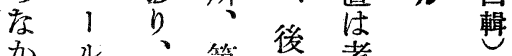

汃儿、第者 考

た索置第な色

の り は

に 難最 た セ

致加に位卡は $\mathrm{Vp}$

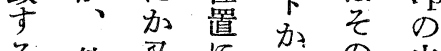

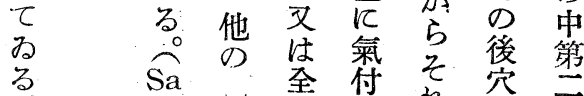

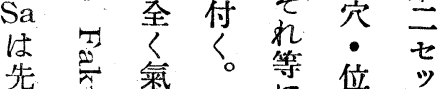

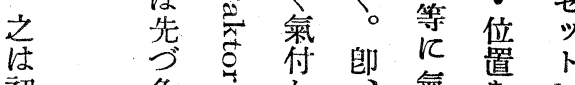

色子加氣老で

分よ佂特付考早

あ初 万

色市芯

置初

期

き程

色苏索

$\mathrm{Ri}_{2} \quad$ 數

ら色る

何 悉 $\widehat{W a_{11}}$

番 $\stackrel{\mathrm{Mo}_{1}}{\mathrm{Wa}_{0}}$

$\checkmark$ T゙

順 市

類重

序

が

り 改な 位を野は像

め岁监 考 野は、豫

て 老慮の實老六

返期 位 が課学論驗立

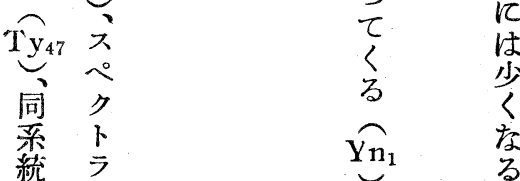

置示 L 入 文 I 乙

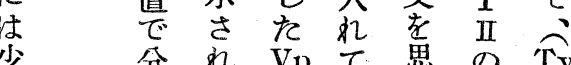

分就 $\mathrm{Vp}$ 思 の $\mathrm{Ty}$

類る

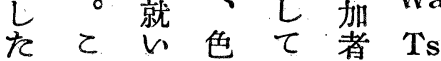




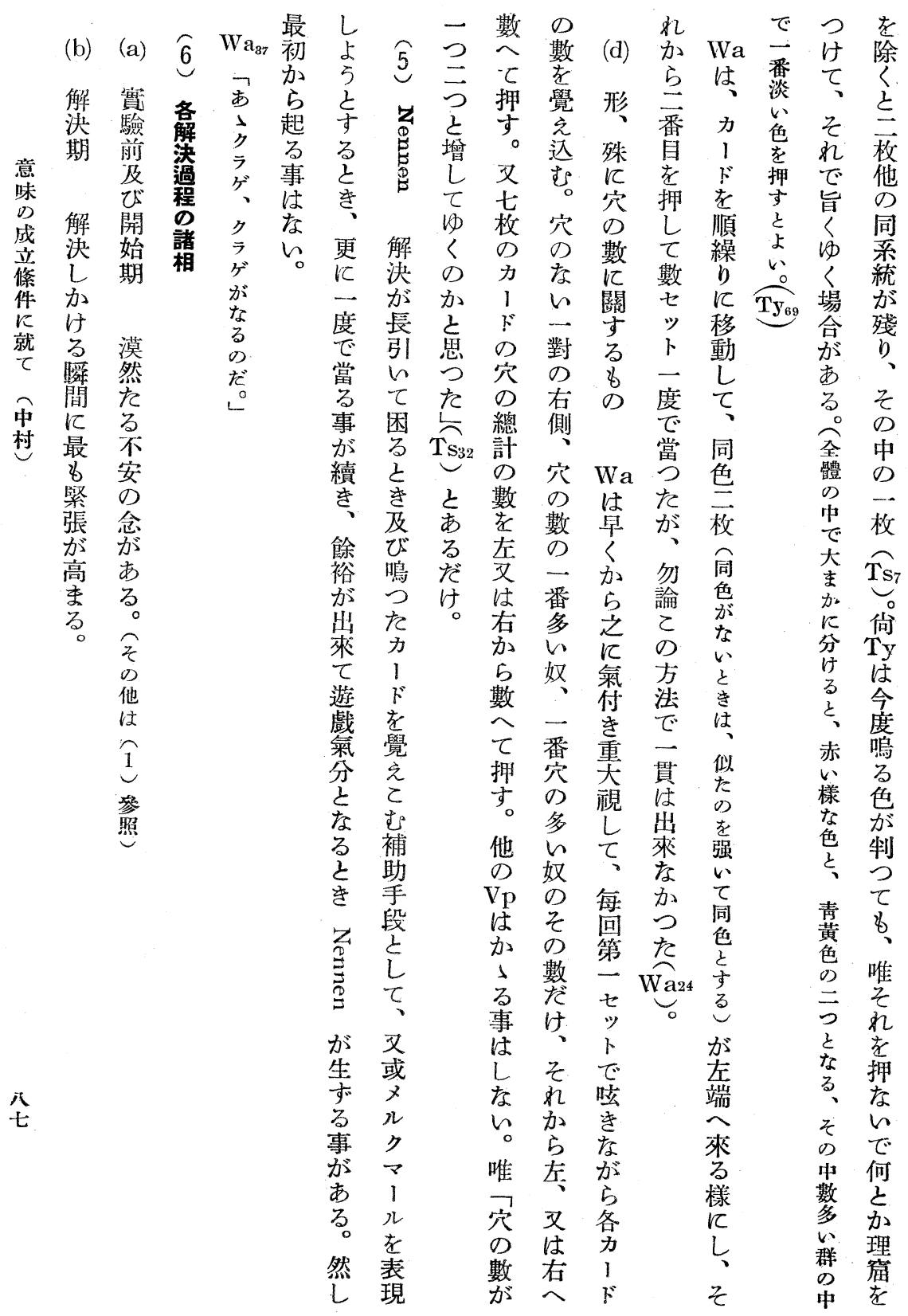




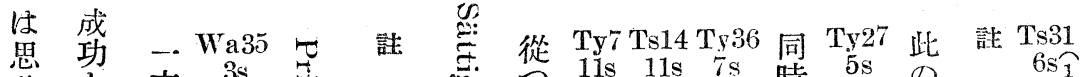

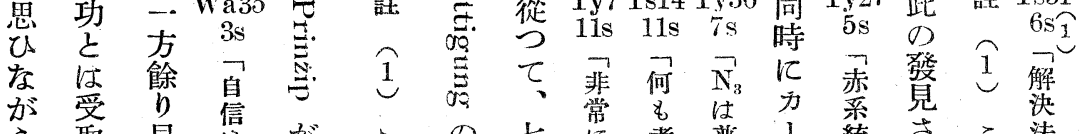

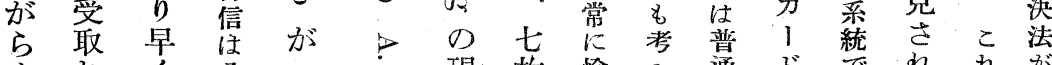

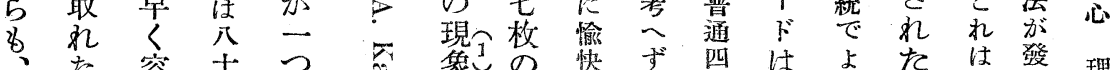

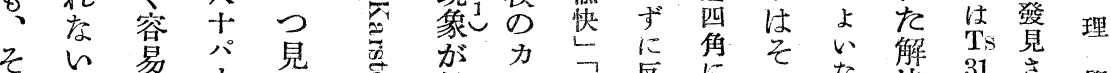

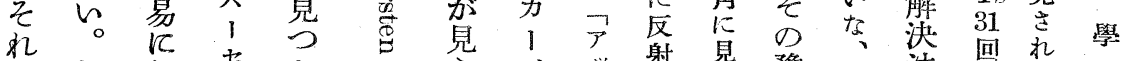

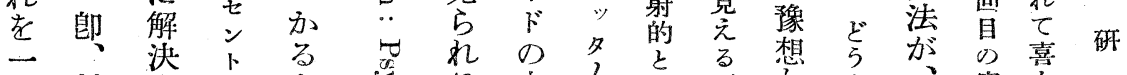

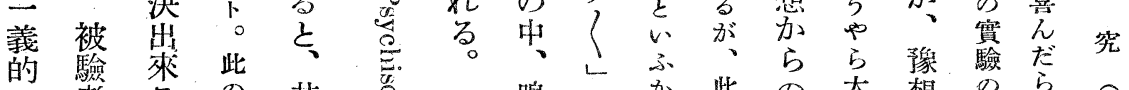

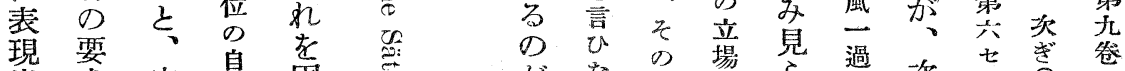

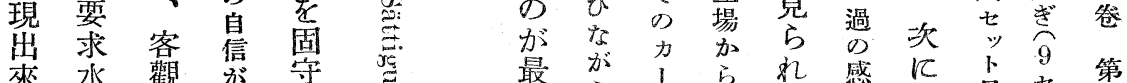

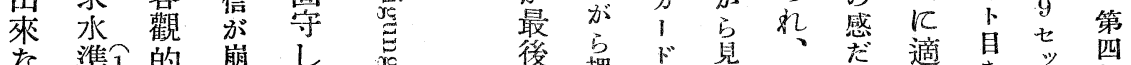

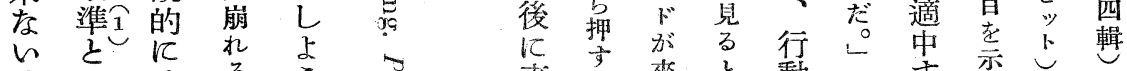

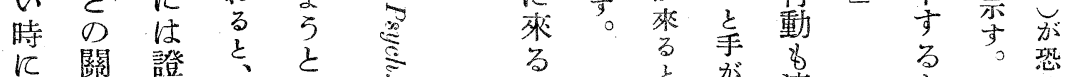

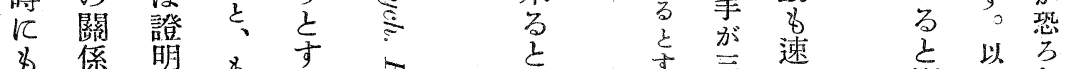

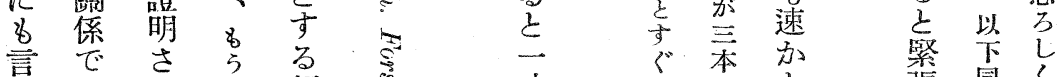

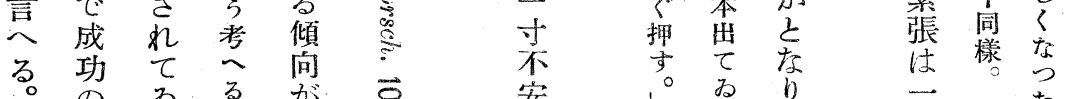

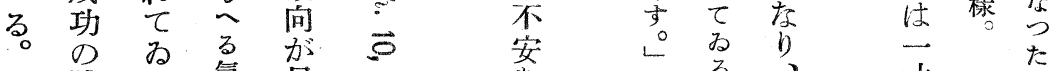

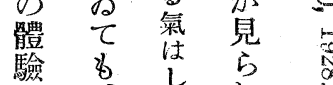
が、息れ

生 主 觀 。 万的 ᄂ 少

同注

\begin{tabular}{l} 
考 \\
感 \\
る \\
る \\
佾 \\
同 \\
\hline
\end{tabular}

栐文

事 真

は田解

何 决

加

否

實

驗

繼

續

古

万

時

は

莺䂑 緊

は

が

号

西之

緩

と が 


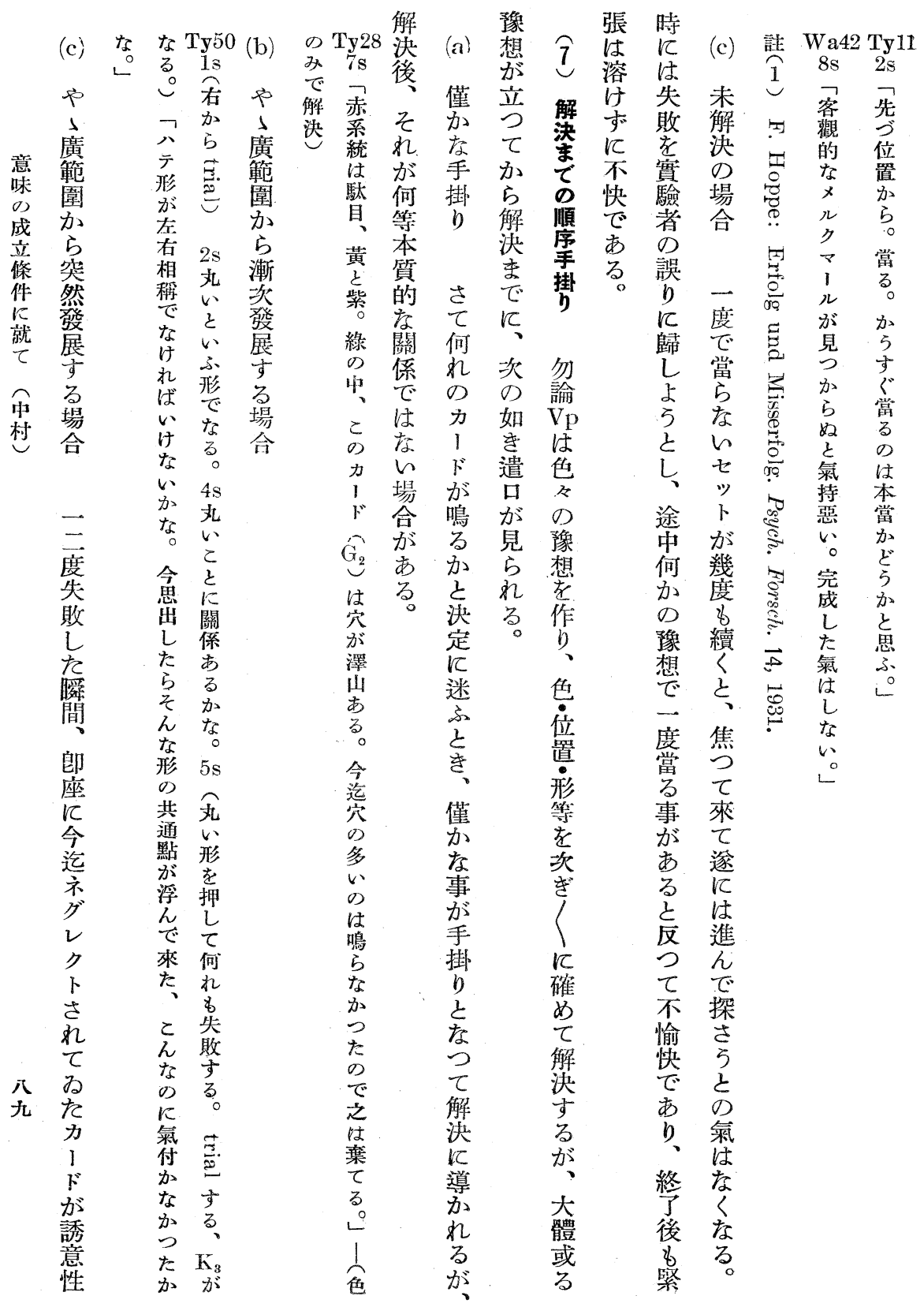




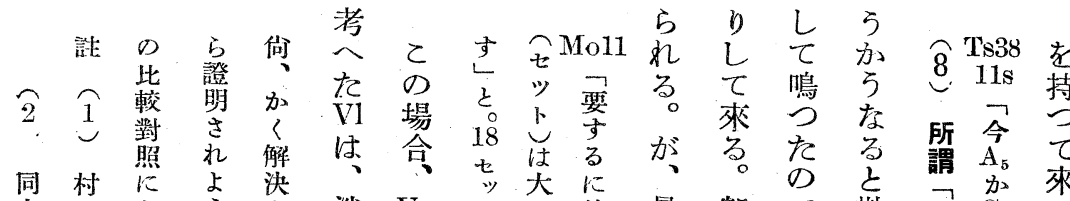

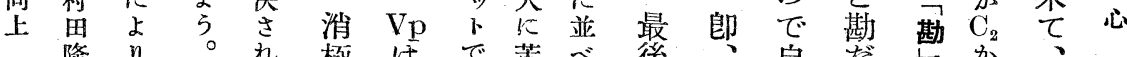

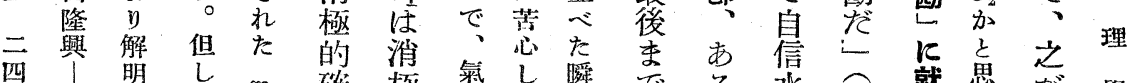

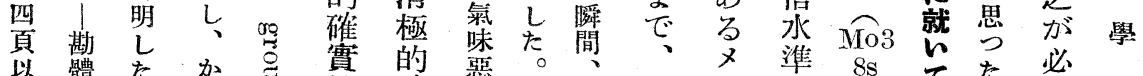

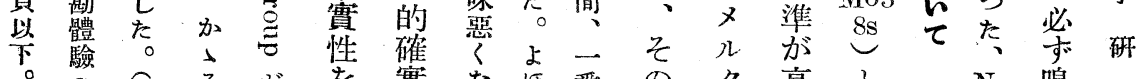

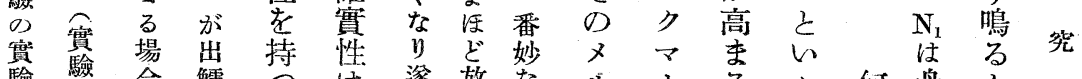

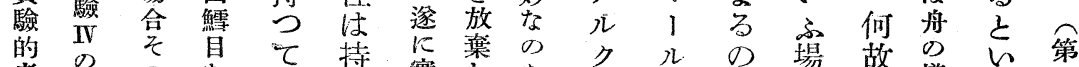

考方 の な て 持實し 笔第

察法哭

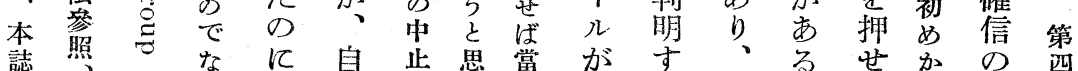

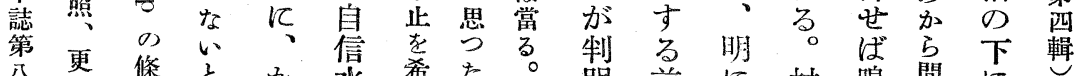

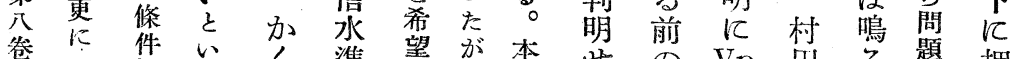

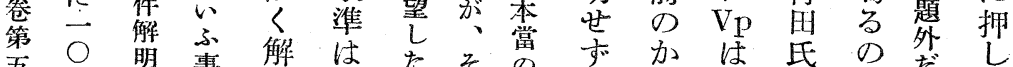

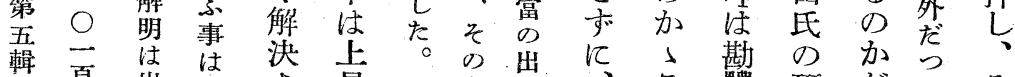

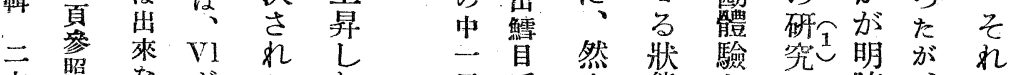

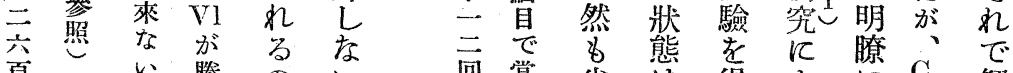

頁 心 滕の

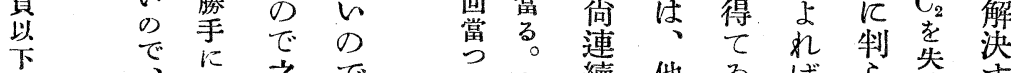

そ心 劣勘 色

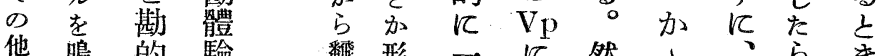

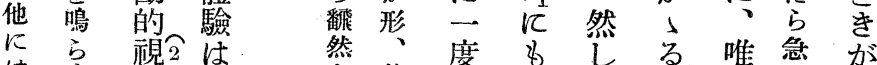

は 卞 視己は

次㥎皇

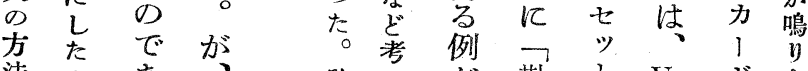

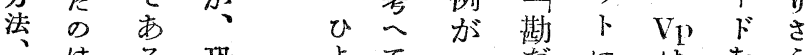

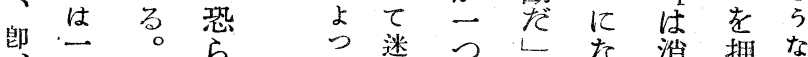

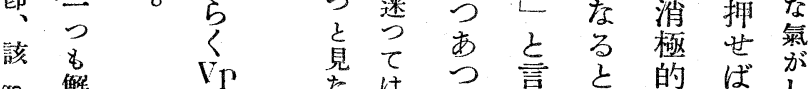

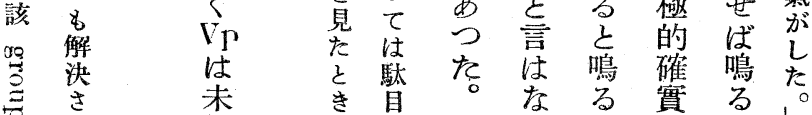

九

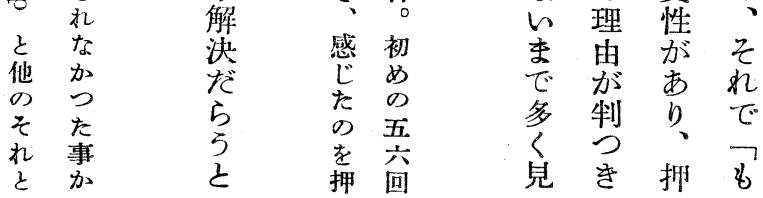




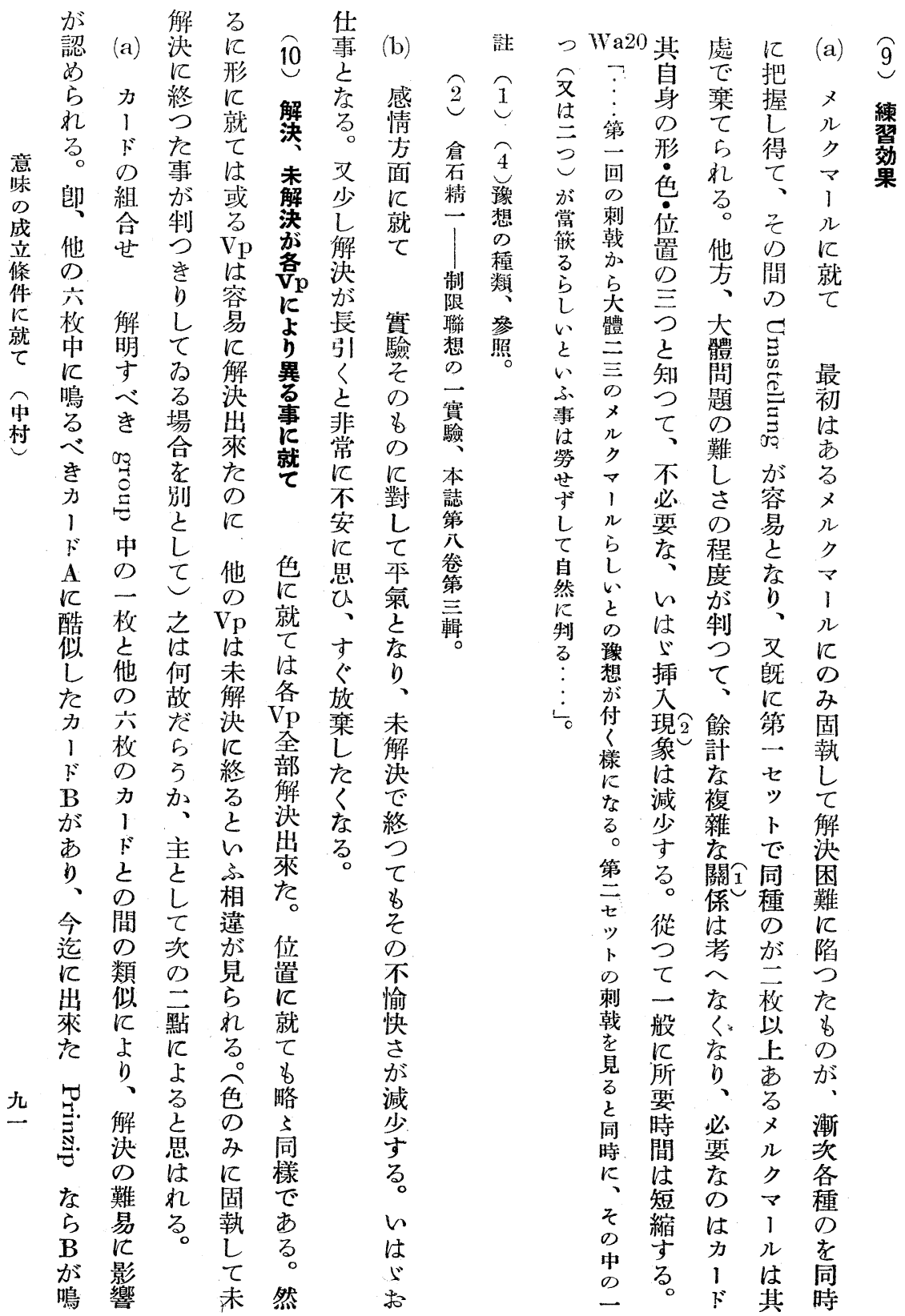




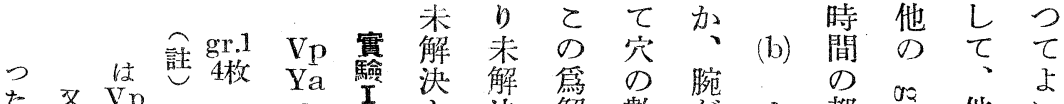

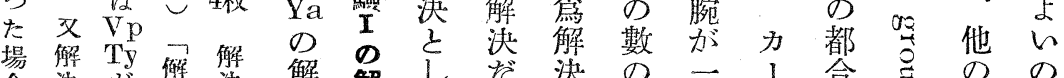

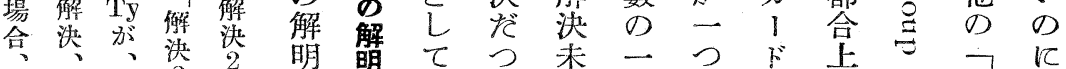

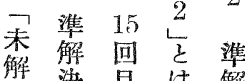

触決自注解

定 實 決 1

ほ 解 驗し

各決でた形

七子、 Vp が

”區第 が 割

何別 2 二 合

度集究人出

女用占る

失子以 以 足

敗る後之主

しが解をな

遂解決示市

に決た。の

何し の 準

關 既 示解 $2 \mathrm{~s}$ -

係述高 1

乞 如每

ルく、同

鳴 $\mathrm{Vp}$

る が $\mathrm{Vp}$

加の x

全席必

然度落名

明當到

場る る ル

合

準儿中

準を代隹

触鳴表

点妾的

अ

解交弆

決架尚

程續曹员

度 的

置光解致市方不の色、

几力決不当見可力长 $\mathrm{B}$

て 粱 9 等方能 1 等 が

差䍃差致 の の の

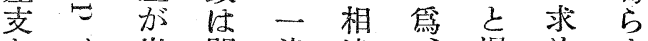

な出問載違渄め的

n 他來題的一他刭 $\tau$ 亿

と る る 關 の

思 $\mathrm{Vp}$ 出係あ $\mathrm{Vp}$ る解が

心江委学名場決鳴第

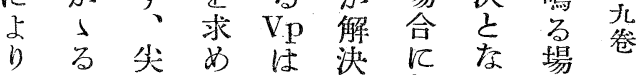

解 兩 つ占圖高起 。 合第

決方た 5 形风る。四

ざ 圖と索ば。こ あ 輯

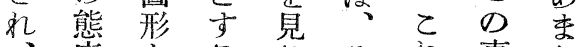

度とるる 子衣事り

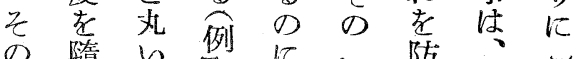

解隋圖等

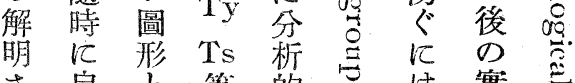

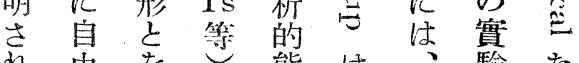

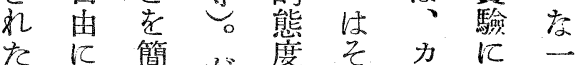

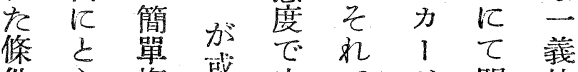

件 方複或完で占明的

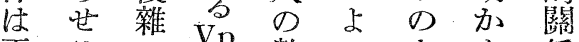

更る の $\mathrm{Vp}$ 數 々 あ

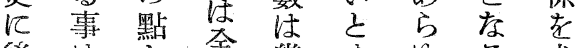

後は等㻃幾す倵求

充 方㤱つるるがめ

實分一的一。組能文

驗出緒態 叉合問

で來に度全起る

吟をすを體索の Vp

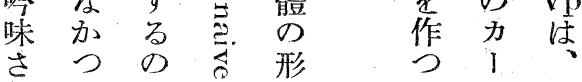

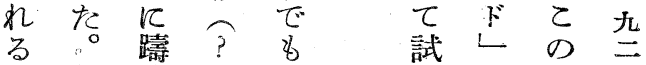

加然躇 乙 丸

みがけ

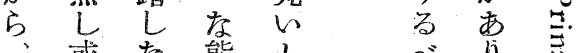

未或な態占萃方怘

解 $\mathrm{Vp}$ 例で四它々老

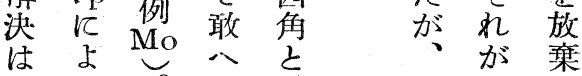

でなと 


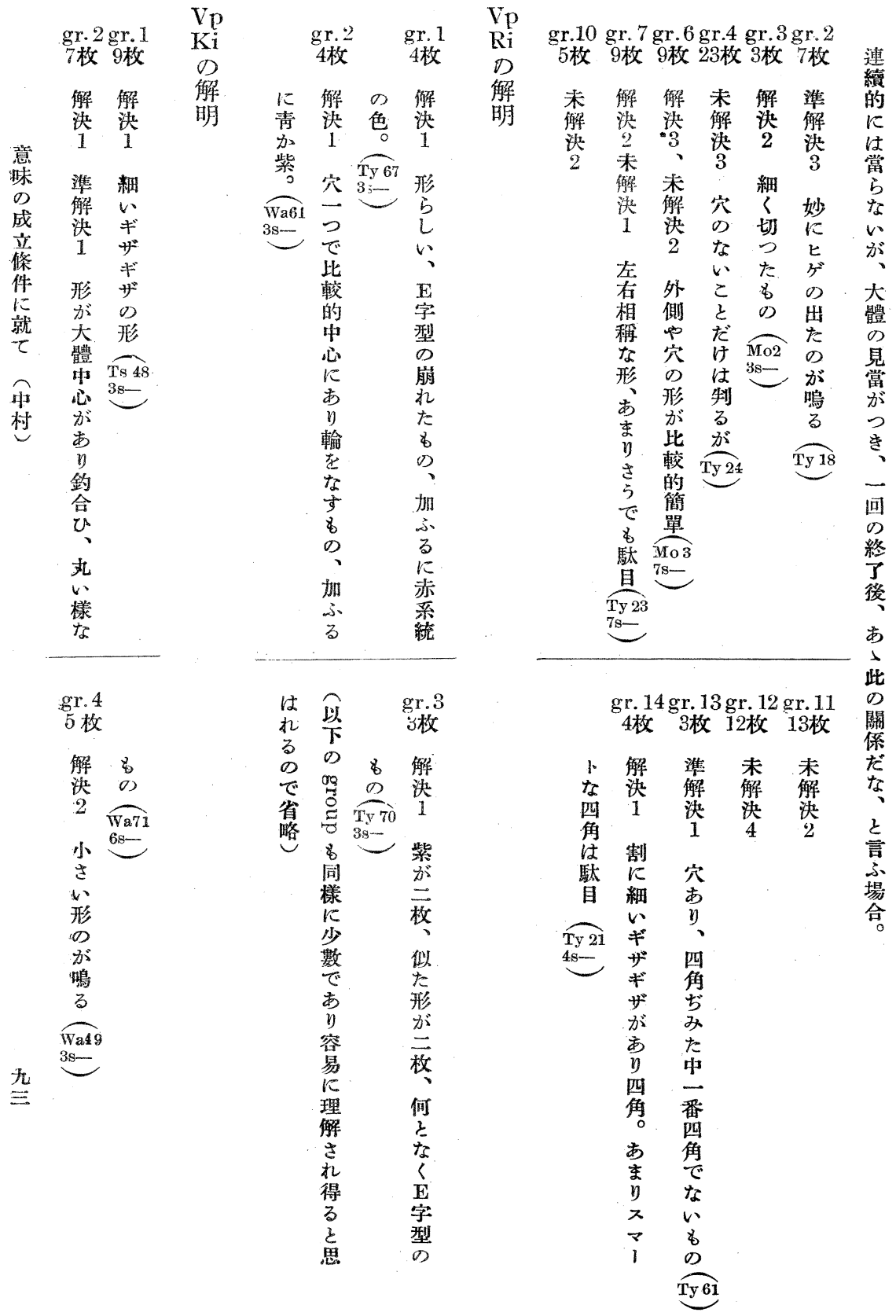




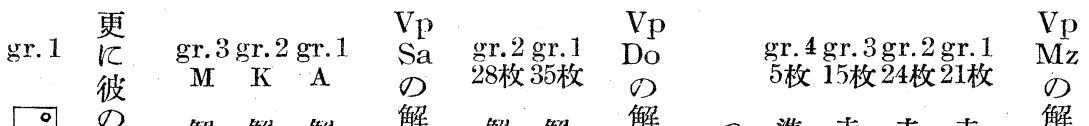

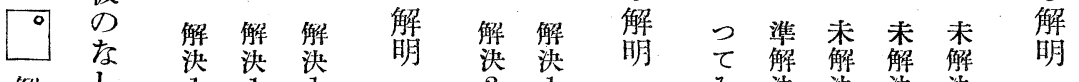

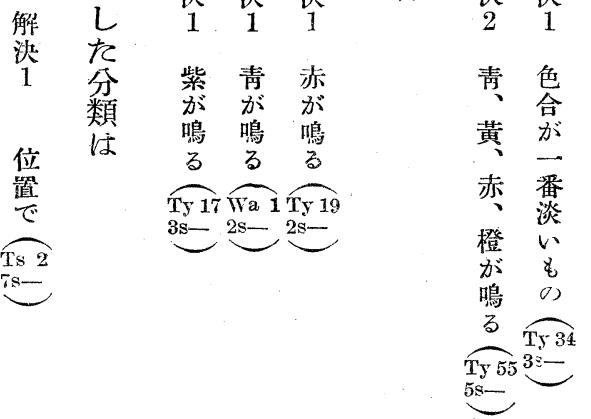

四

面

輯

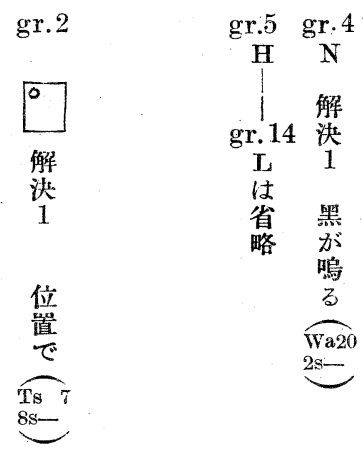

gr. 3

35 枚

gr. 8 gr. 7 gr. 6 gr. 5 17枚 7枚 4枚 万枚

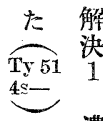

$\begin{array}{lccc}\text { 未 } & \text { 集 } & \text { 解 } & \text { 解 } \\ \text { 解 } & \text { 解 } & \text { 決 } & \text { 決 } \\ \text { 決 } & \text { 決 } & 1 & 1 \\ 2 & 1 & & \end{array}$
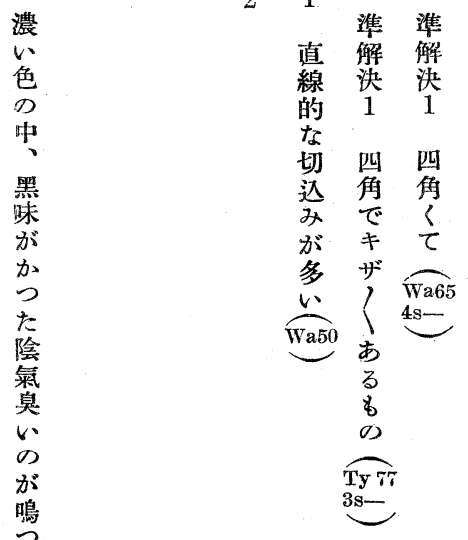


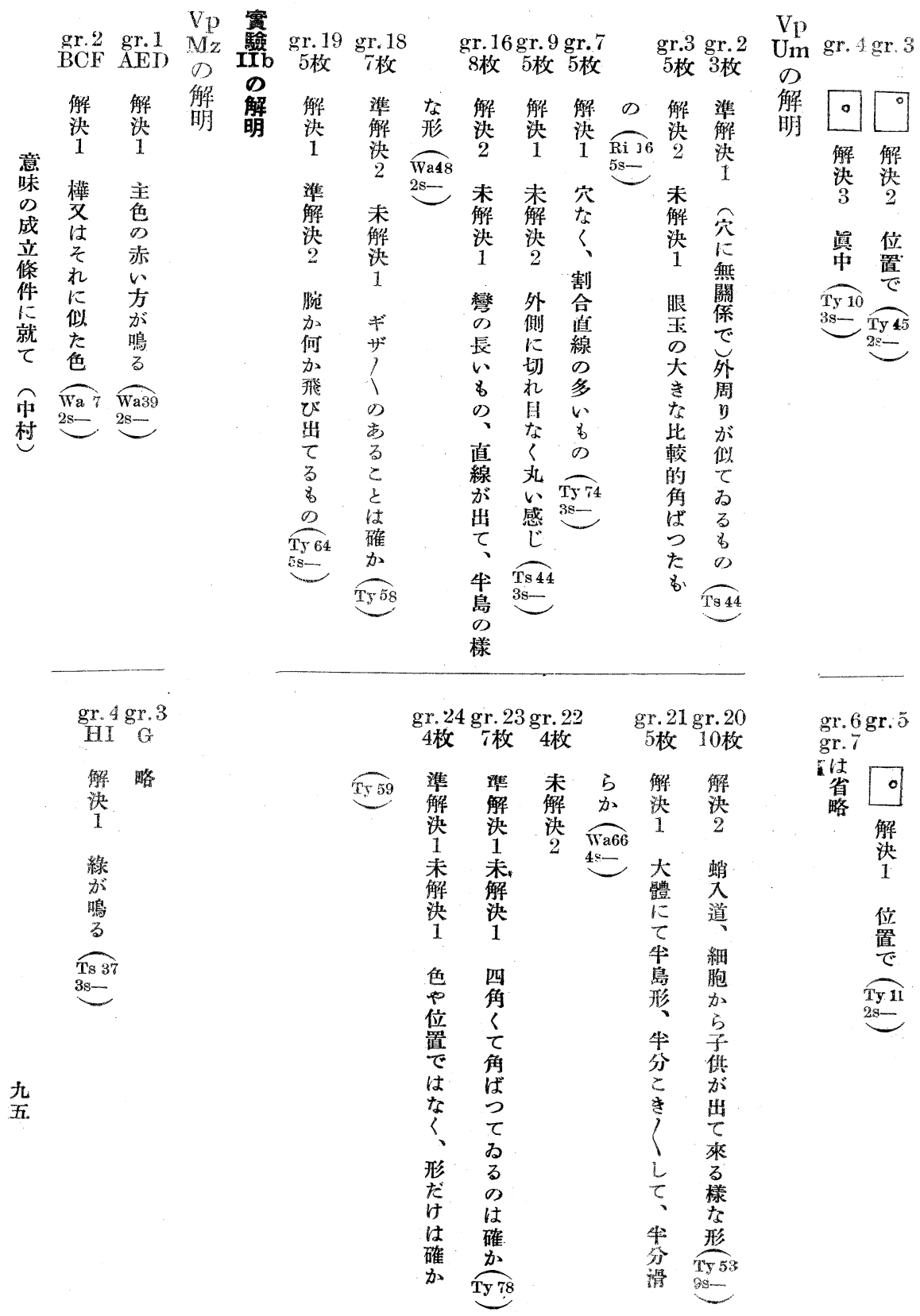




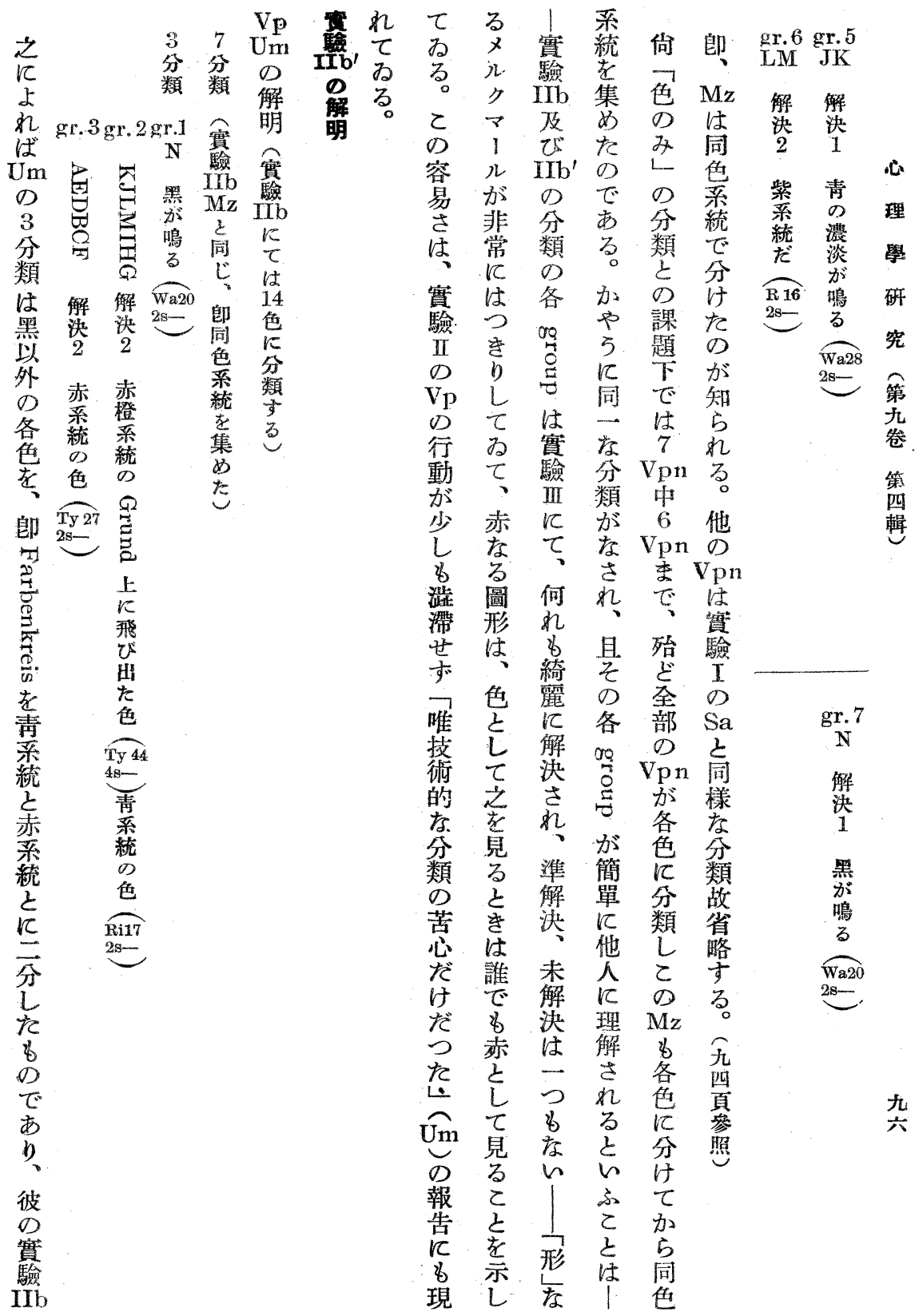




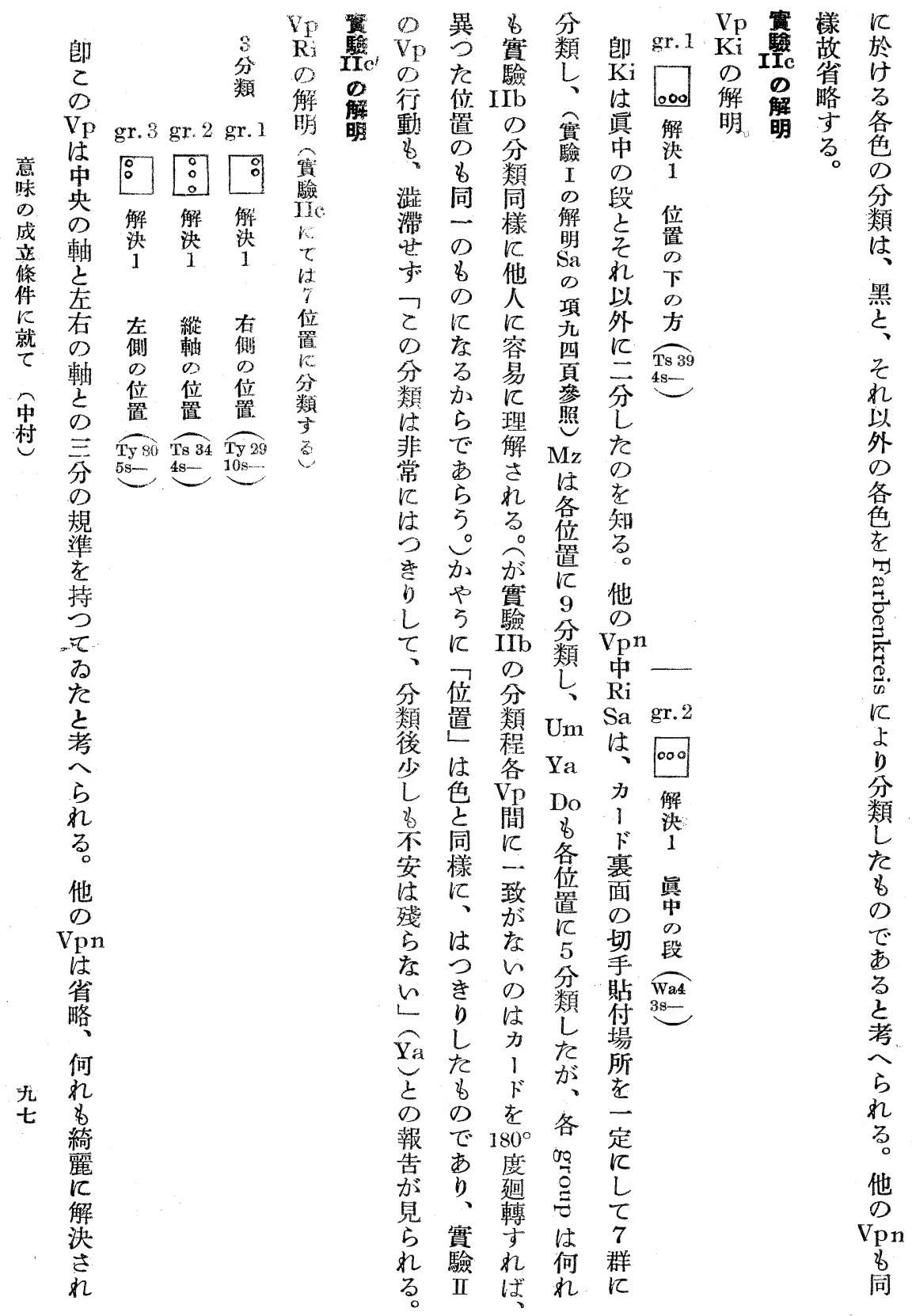




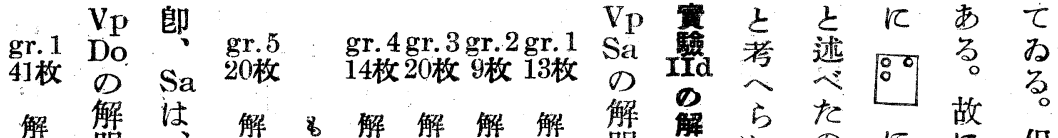

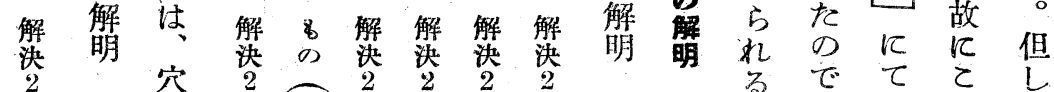

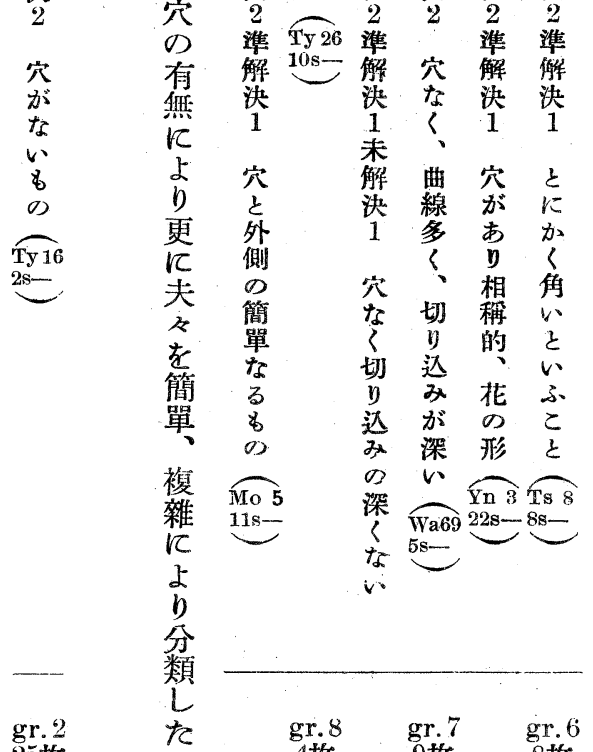

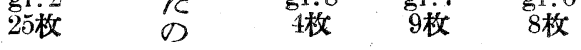

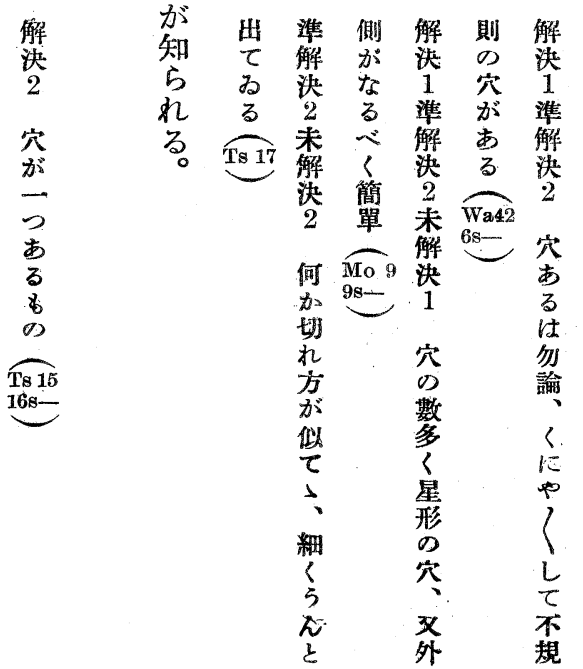

吾で て

そ 再 Wa

の試解导 2 學

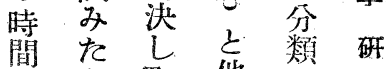

は ら、Ty 他

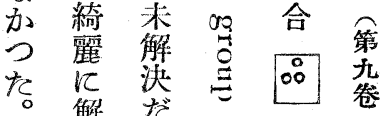

決 方は 第

出たを来筃

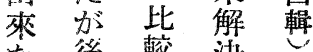

t後 較 決

故尼せ

机位る

米置 事 Mo

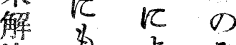

決占み

の E り 解

多穴害 決

位蓉 ᄂ

$\therefore$ 道

E 方

再点

び位照 番

課直 妙

ᄂ 学位柆

を古置

万等的の

解をよを

決尔当抑

L

得閣のば

る笔上鳴

无等省

は古方点

な各を市

的索更尔 


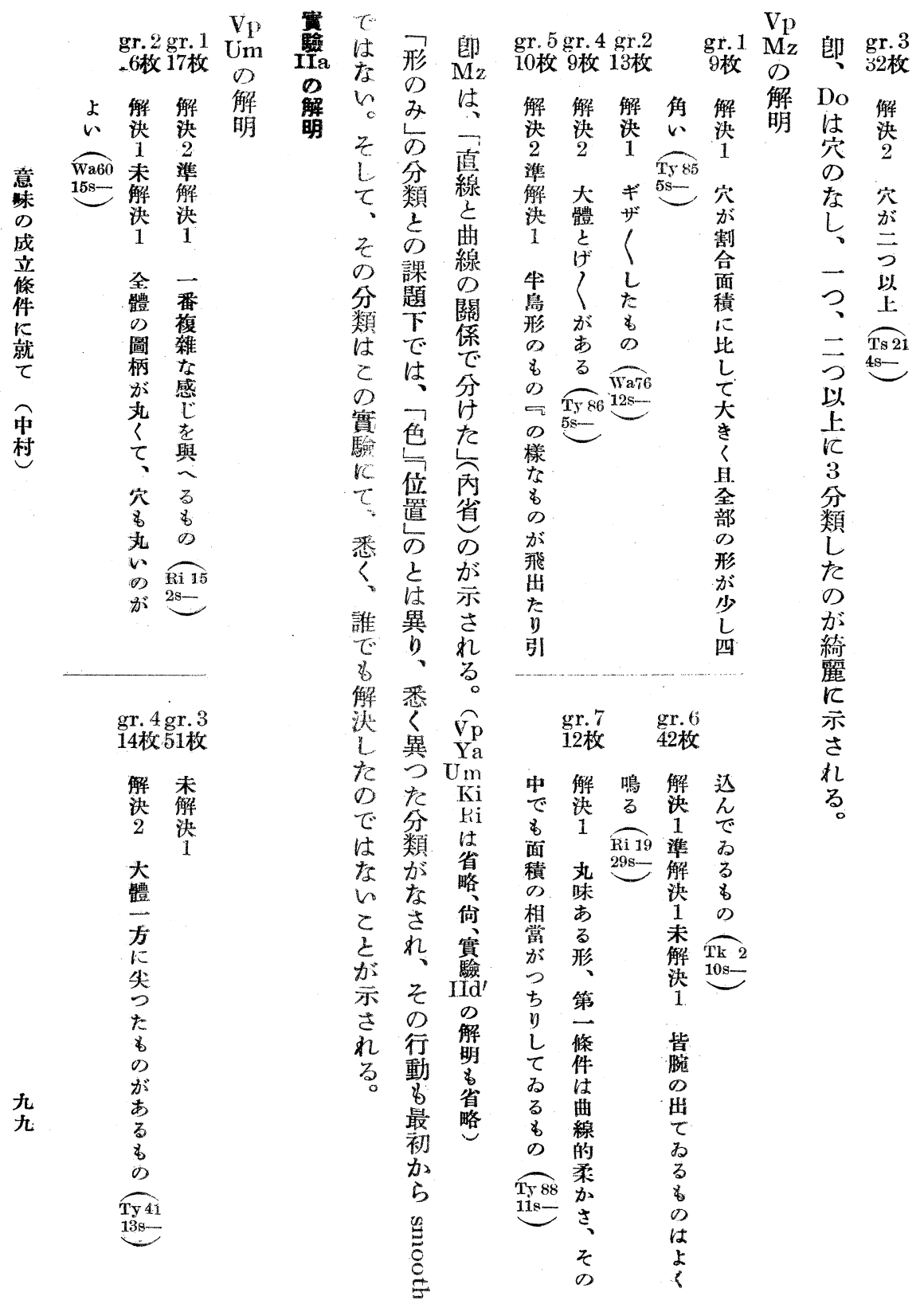




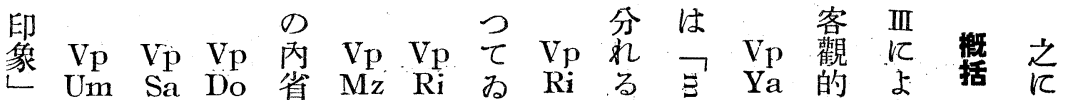

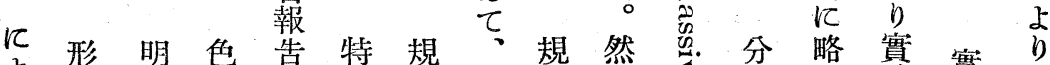

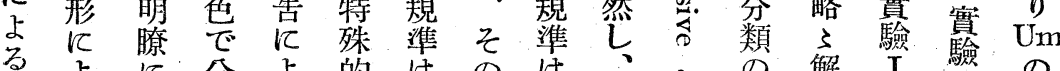

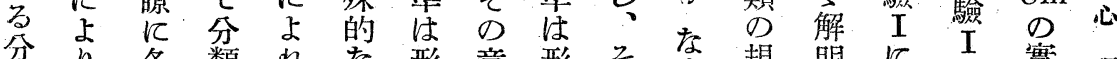

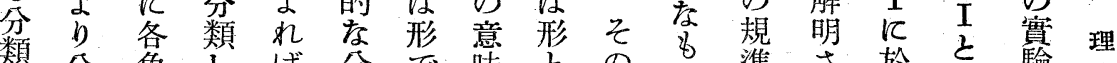
之 類 に 色 し ば 分 で 味

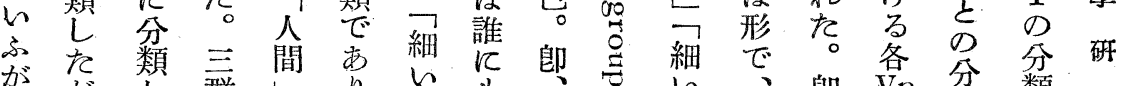

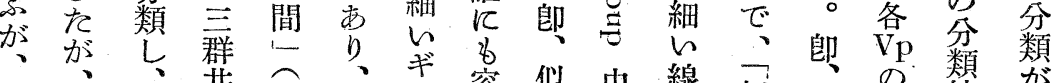

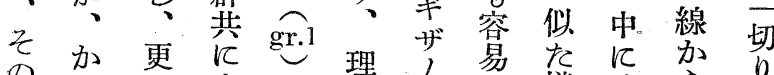

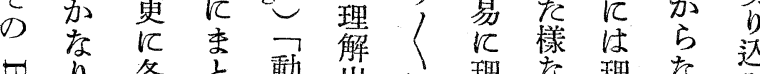

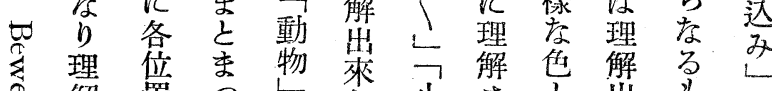

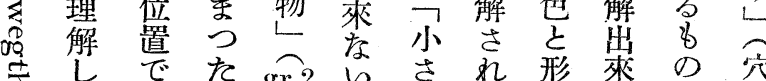

志蜼 で た

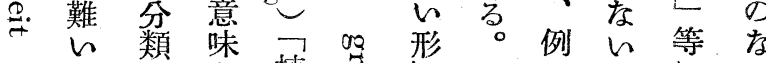

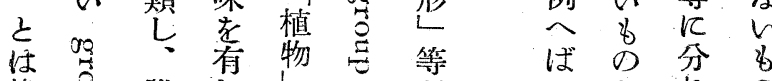

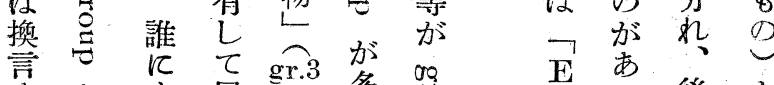

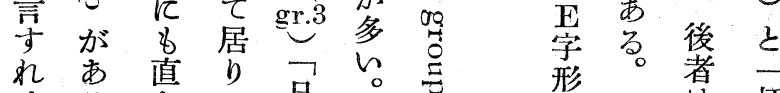

は る

キ $\mathrm{Um}$ 理 淡 本 三

ザの 解色生 文 り

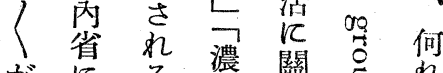

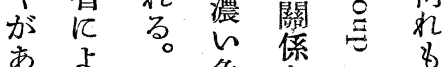

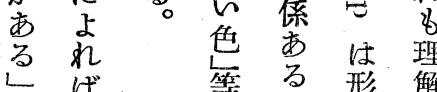

しば、等 る 形解

割圖 が の 分容

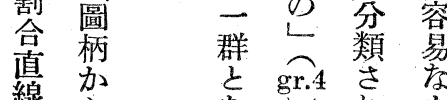

線

が來年等 れ

多來る つ 志奆 の

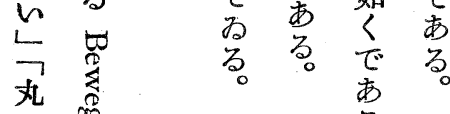

b

感

る゙

$\mathrm{Mz}$

沓

は切

で赤令拔

采簢 拔

\begin{tabular}{lll} 
統 & 單 & な \\
色 & な \\
\hline & 形 & 完
\end{tabular}

の 類 が 究

種果第

異些管劣

分較第

類對方四

の 照の

各公が

夏定

熊さ

が台れ

理 ら。

解賽 何

设 I Vpn

得のは

る 分 省

否類 咯

- 0 另規

老左古

つ右

た稱爰

數年

力 睁

1 ぢ 别

ド みさ

がた的

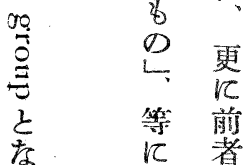

規 略

準推

之 定

意它

成 如

立更

條化

it

何 の

加貫

が 驗 


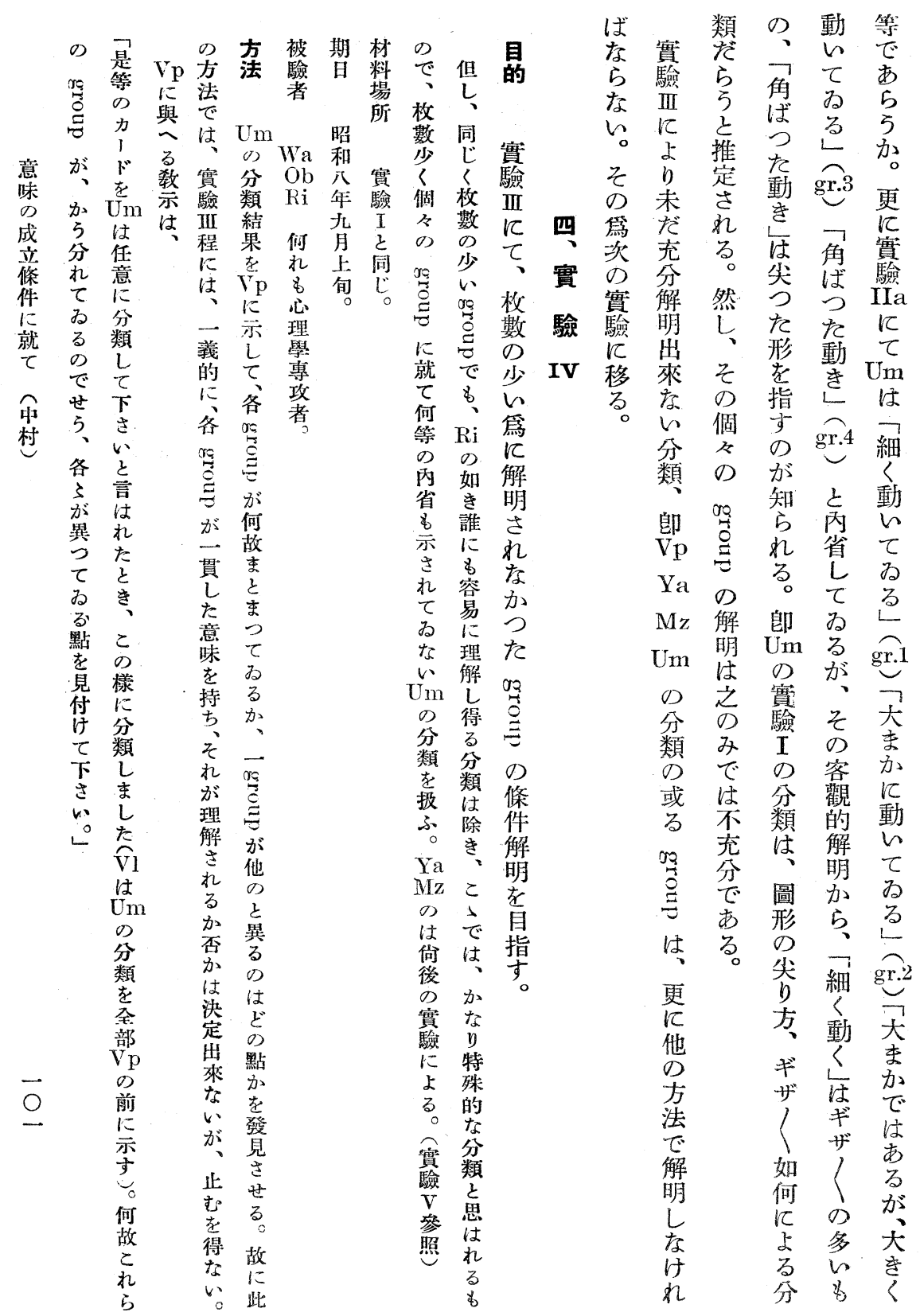


gr. 14 gr. 13 gr. 12

gr. 11 gr. 10

gr. 8 gr. 6 gr. 5 gr. 4

gr. 2

gr. 1 結 2枚 2枚 5枚

3板 2 枚

3枚 1枚 1枚 2枚

3枚 3枚 笨

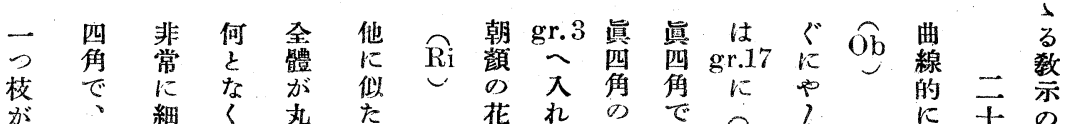

出飞

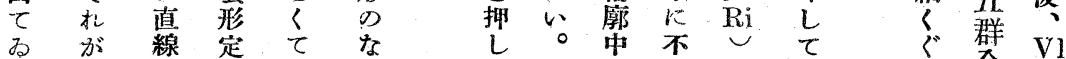

る 切的規大

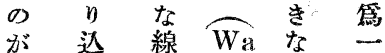

吕达線 $\begin{array}{ll}\text { Wa } & \text { 穴 緒 }\end{array}$

く年組㤎に

似吉 合

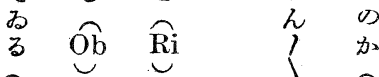

$\widehat{R i}$

Ri $\quad \underbrace{}_{+} \widehat{R i}$

み が の 嫢 入 比

* $y$ y

形拔穴吕扎

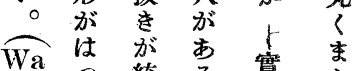

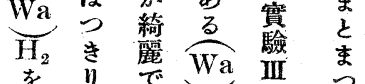

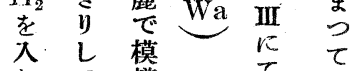

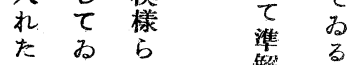

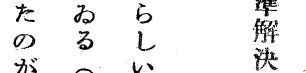

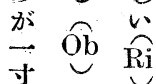

$\overparen{\mathrm{Ri}}$

米

b

全

心

理

學

中 部 見

〈で悬研

しな割

究

おく似

第

る

吕 思 第

$A_{5} \quad K \quad$ は

輯

二解る

$\widehat{W a}$

戀決

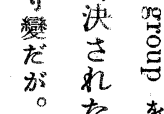

$\mathrm{M}_{\mathrm{i}}$

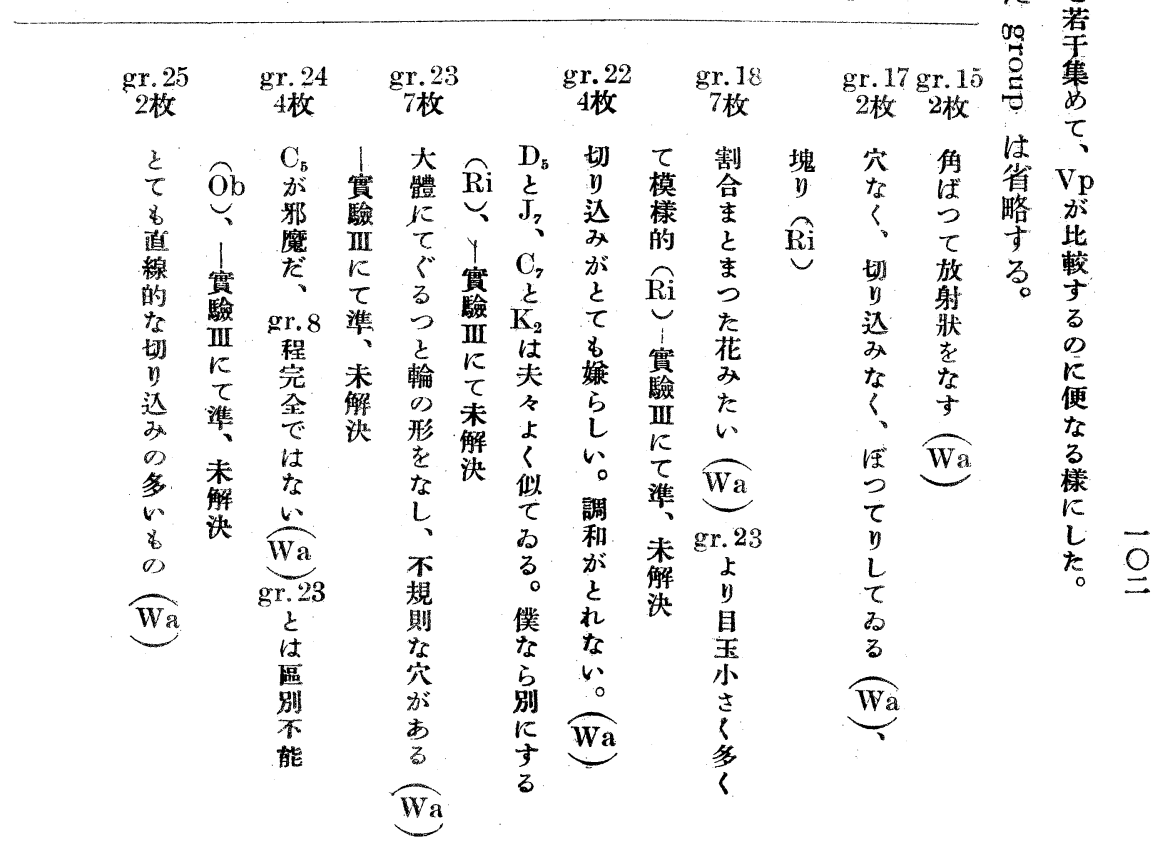




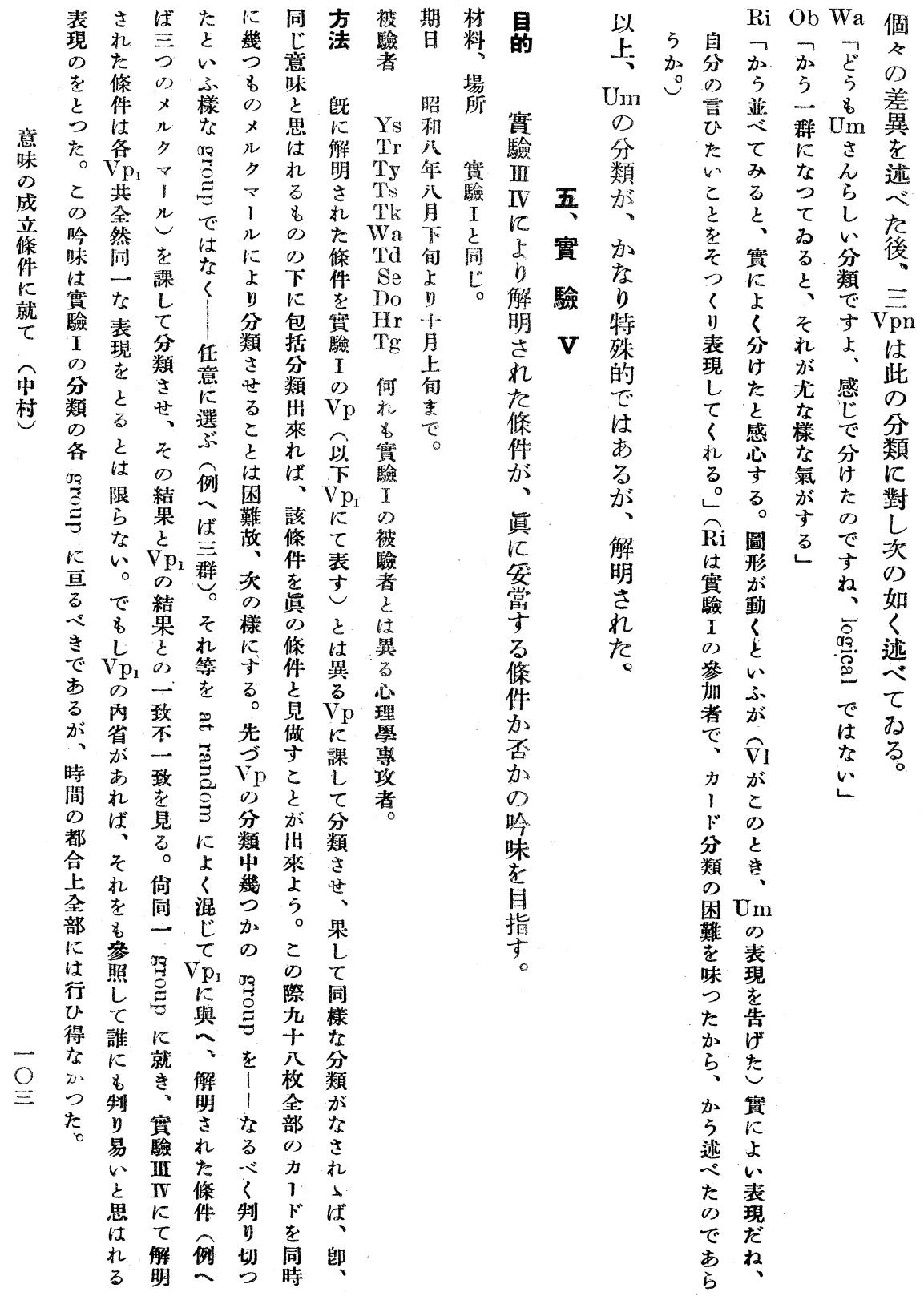




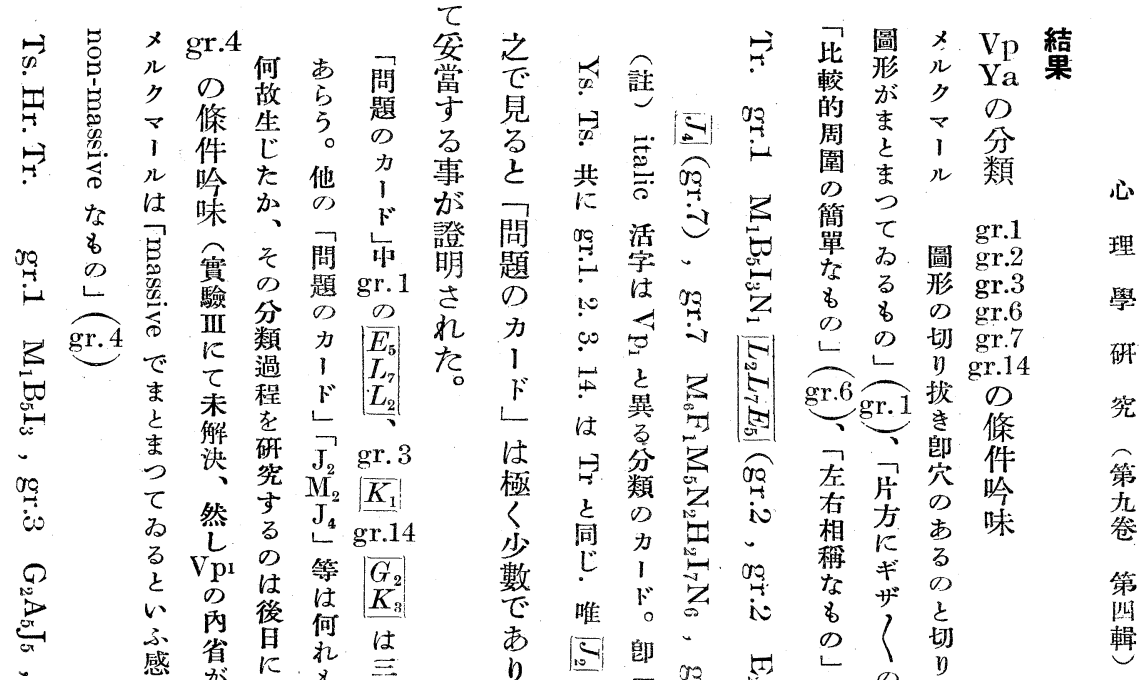

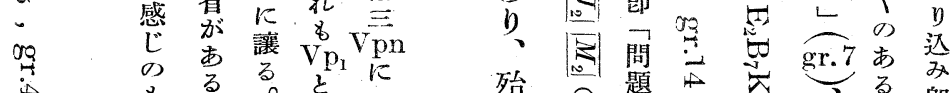

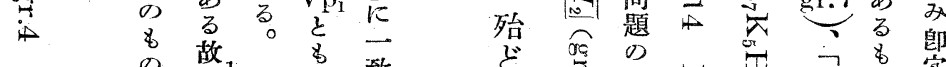

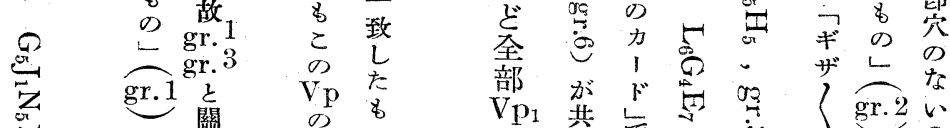

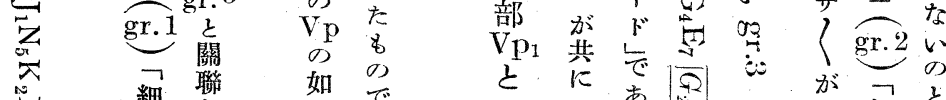

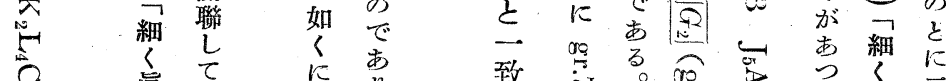

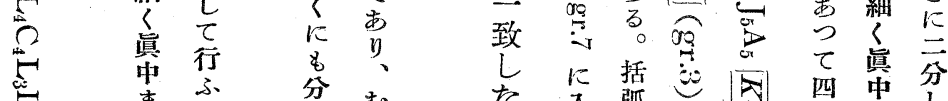

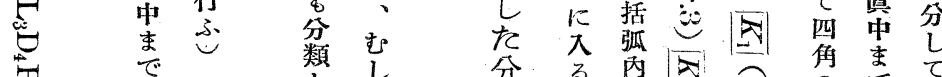

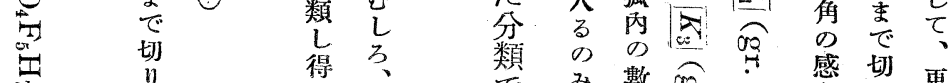

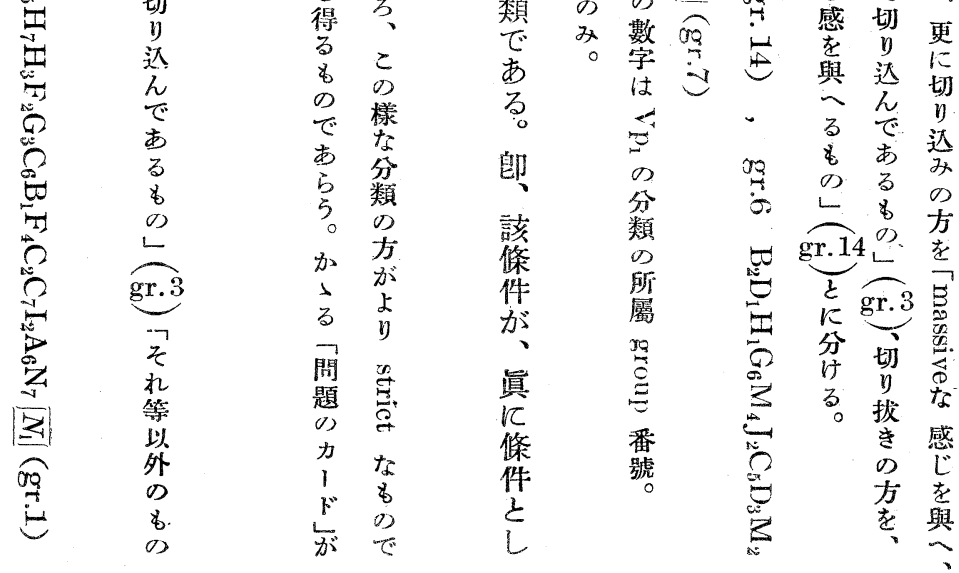




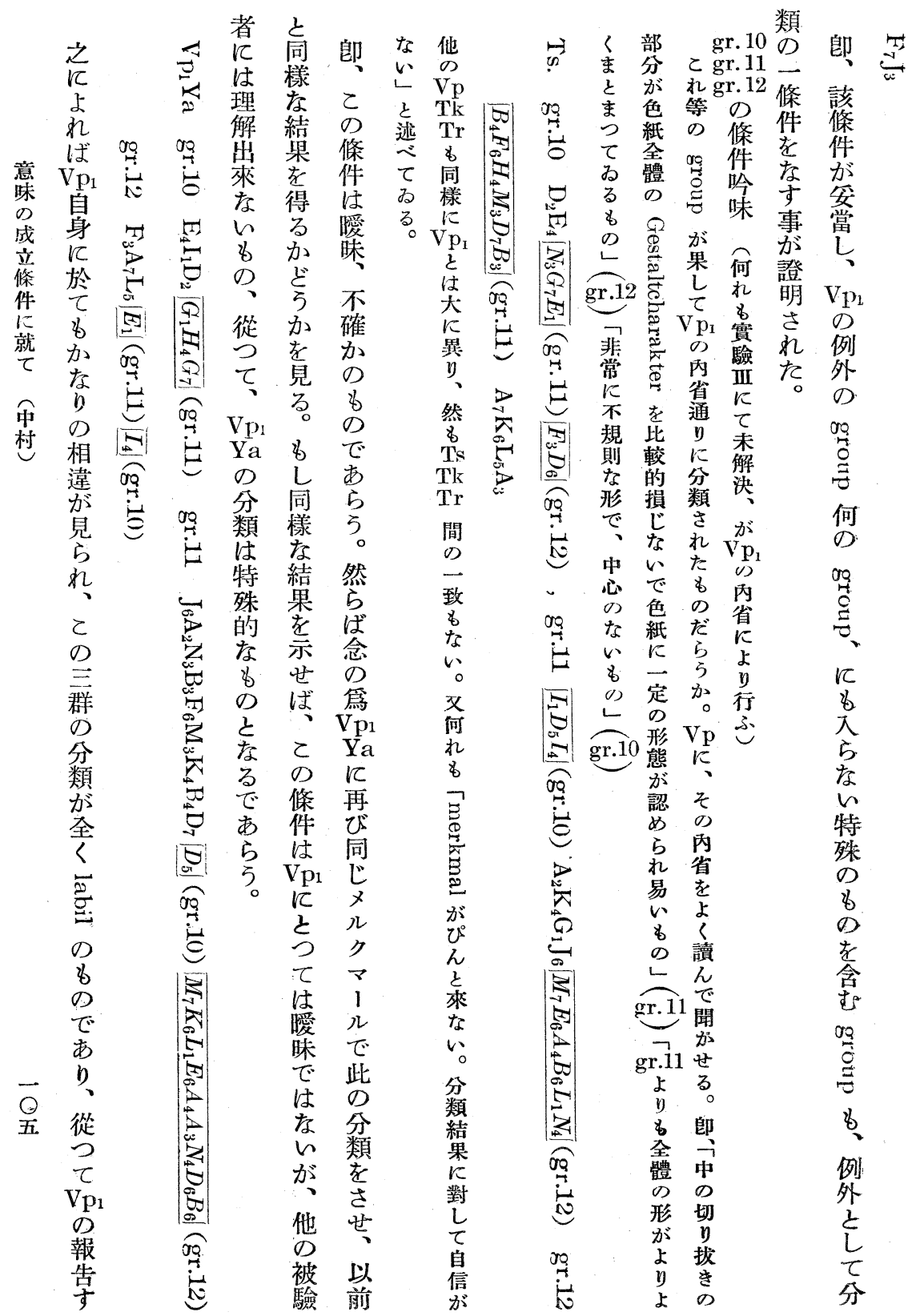




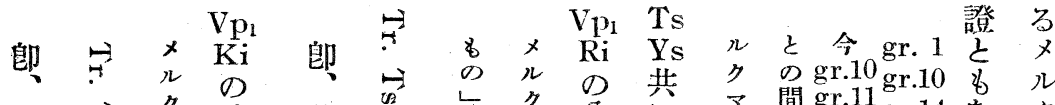
該

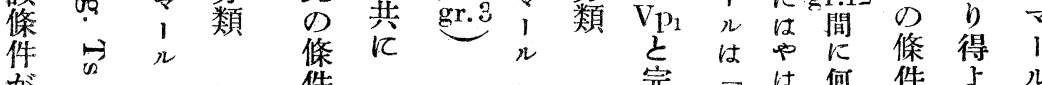
が共 gr.1 牮

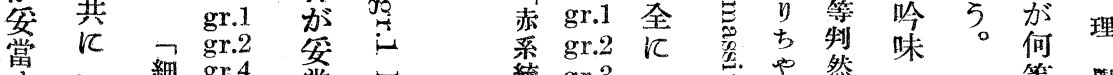
尔

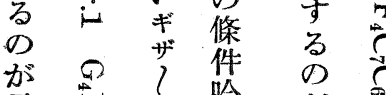

亦焉然味喿喿

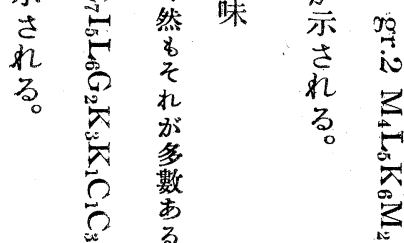

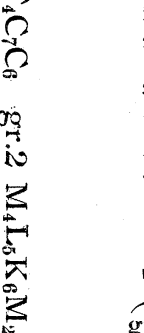

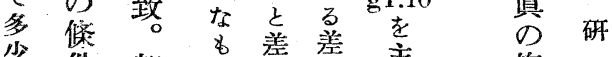

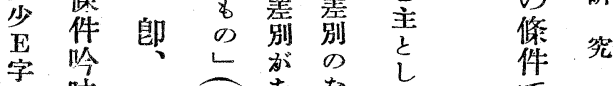

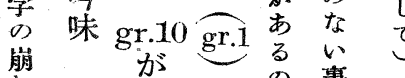

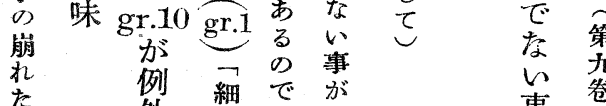

女 外細示

の 組ギなさ

gr.1 竝

๘

D

永觉 形

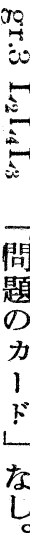

る $\quad \begin{array}{ll}5 & \text { ह } \\ 0 & 0\end{array}$

紫 学 京 郎類

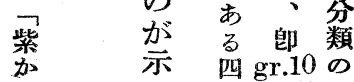

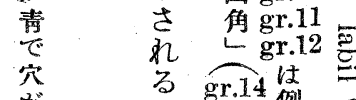

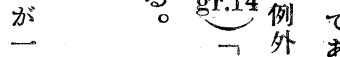

○

不組

九次事

以 L 㔔

外它證

b c

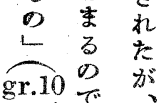

事 卷

が 第

示 匹

さ 輯

h

子

乙

事

は

實

驗

中

あ

l $\quad v$

$\stackrel{8}{\circ}$

$\stackrel{\infty}{\circ}$

な

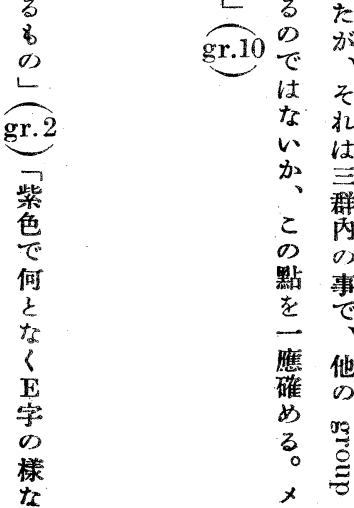

r.

於

w

$\tau$

客

觀

的

rc

解

明

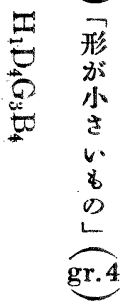

、群

巳

齐 一

條六

の

正

性 


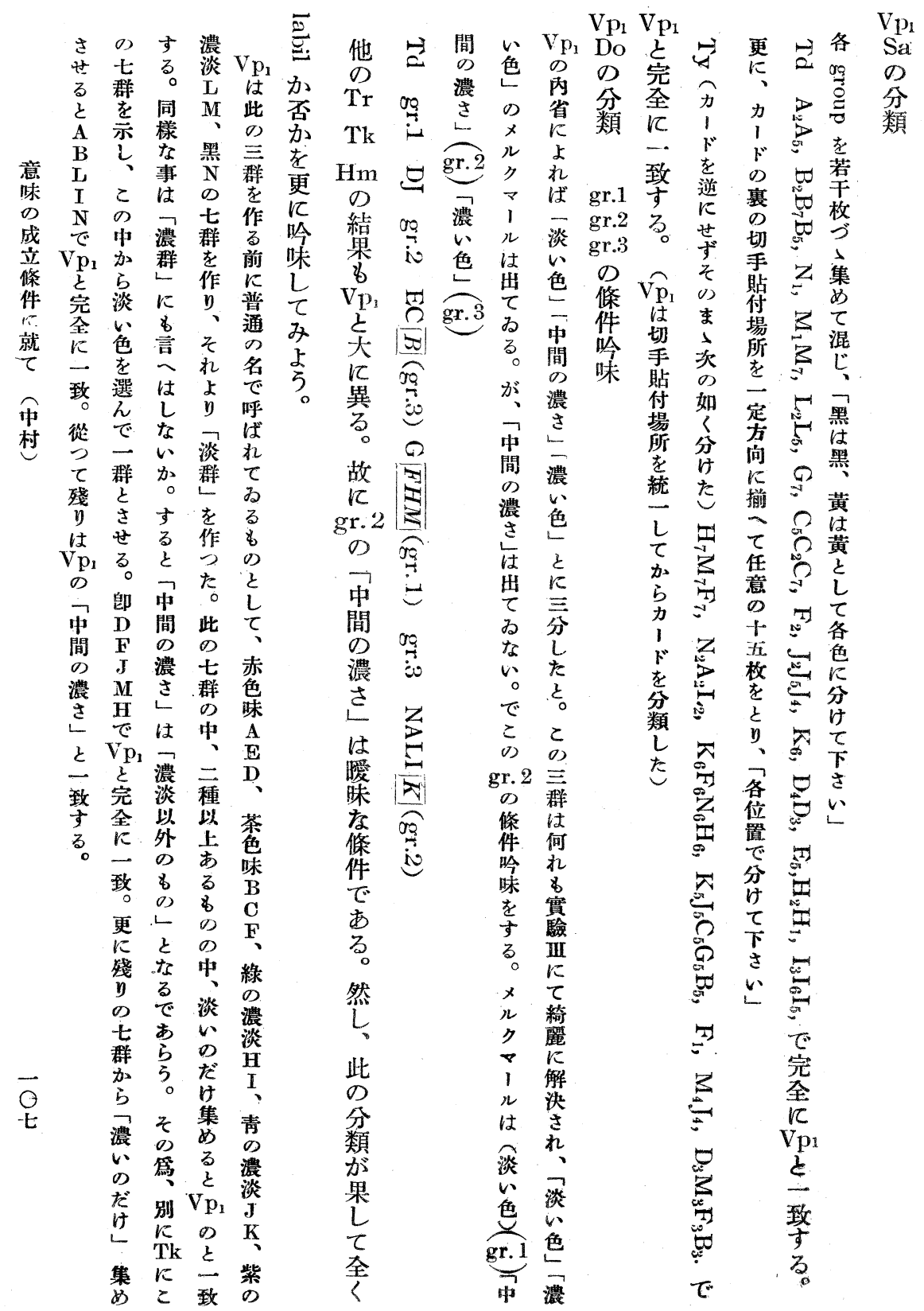




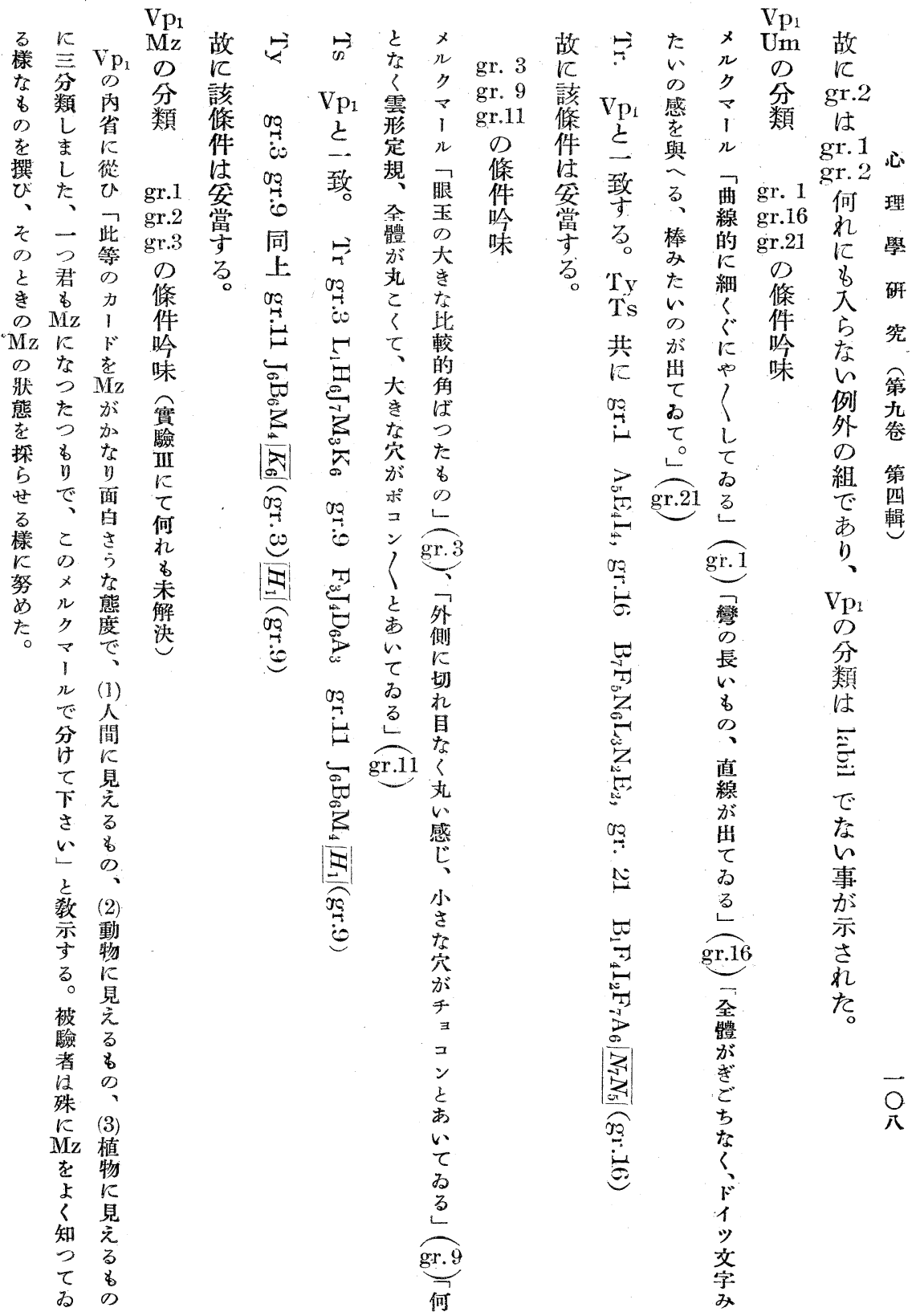




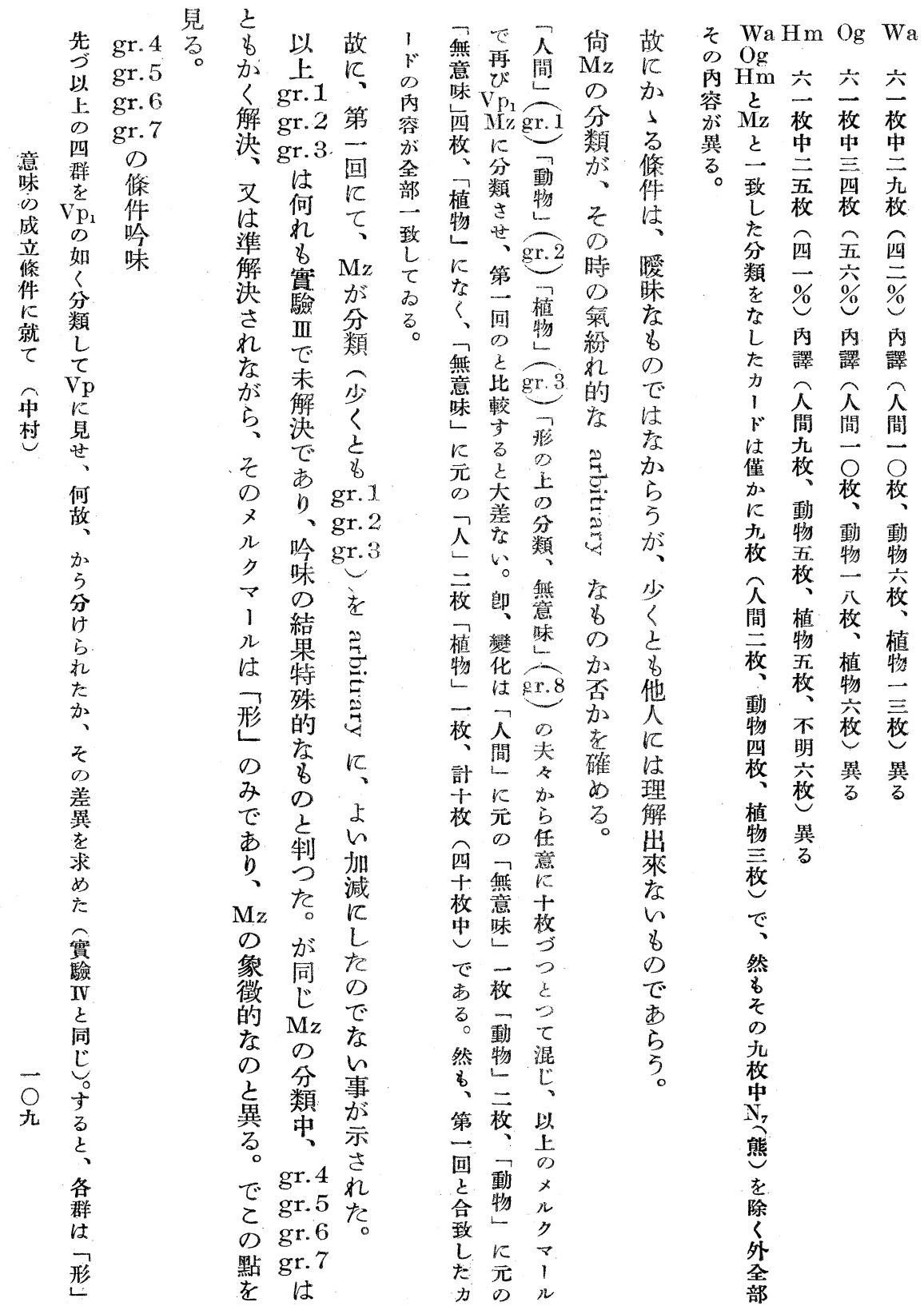


た が 能條 驗て

る 又 成 以 で 件 V 企 以

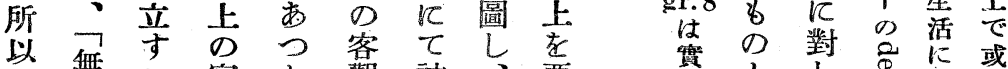

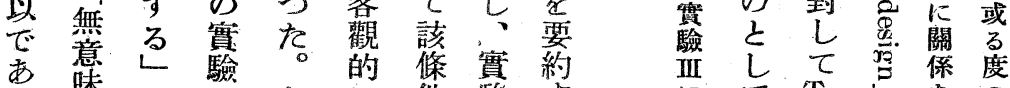

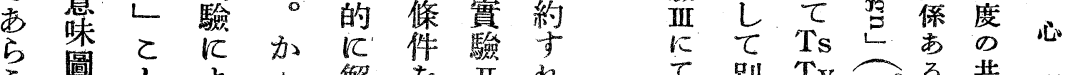

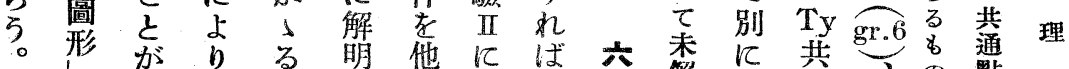

が示

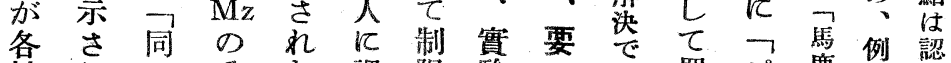

被玑一分疗課限驗

驗た な 類吕 L 分 I

者亡刺はつて 類に

に惫戟特た可正

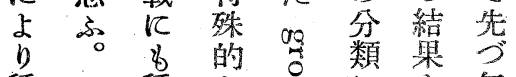

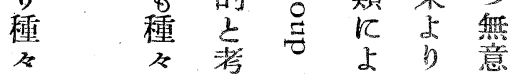

にのヘは它昧

分意 5 、回

類 踘我々 そ艺形

さが・のの踓の

水成乙前條的任

種立省件更意

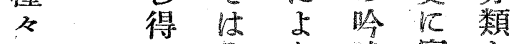

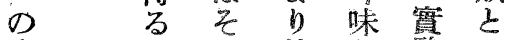

意。がれ他老㽞い

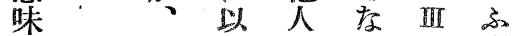

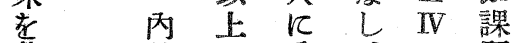

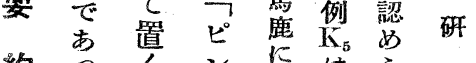

學

約っくン。手朝点究

だ。立手朝机究

分、題

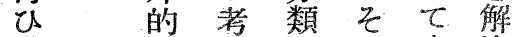

得條察さの客決

る 件にせ要觀孛

乙起進

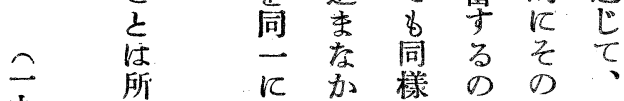

叴謂 す

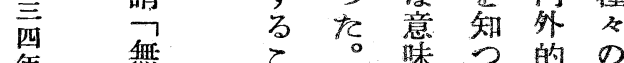

年無 意 皇

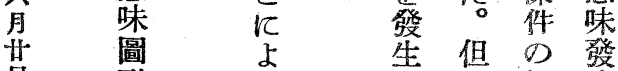

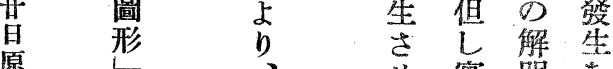

原稿 の

附 受 無

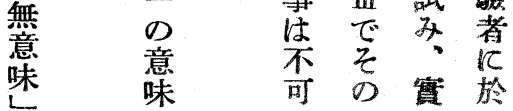

$V_{p_{1}}$ な え

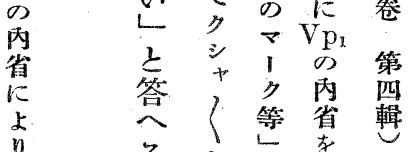

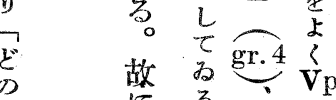

蒫

r

\&

入

な

क

\%

卓

る

で

や尔角讀

は gr.7 $_{0}$ h

b
$\mathrm{M} z$

の 穴 加

分古世

類文飞

が、れれ

他物 䋑

人 年

形学方

理見名

解元 否

出当加

吟萍例竟

壮

L

o)

な で は即

$\mathrm{M}_{4}$

か あ 焦そ

り、等 の

之 ᄂ

$\begin{array}{ll}\text { は } & \text { gr.5 } \\ \text { 省 } \\ \text { 特 } \\ \text { 殊 }\end{array}$ 
(From the Psychological Institute, Tolyo Imperial University)

\title{
On the Conditions of Meaning-formation
}

\author{
(Abstract) \\ by \\ Shigeru Nakamura
}

This study was intended to clarify the conditions o Meaning-formation by experimental method.

Experiment $I$ Problem: Formation of maning

Method: 98 "meaningless" cards were used. They were of 14 different colours, each colour having 7 different positions on card. (See Fig. I). 7 subjects (graduates and college students, majoring in psychology) were told to classify the cards without any limit.

Result: 7 subjects classified them in entirely different groups.

Experiment IT Problem: It was aimed to secure the criteria cf classifications in Exp. I.

Method: This time, the same subjects were told to classify the cards with various limits.

Exp. $\mathrm{II}_{a}$ Classification in a certain number of groups (for instance, $2 \mathrm{cr} 3$ ).

Exp. $\Pi_{b}$ Classification by colour (of the figure) only.

Exp. $\mathrm{II}_{b}$, Classification by colour, but in a certain number of groups.

Exp. $\mathrm{II}_{c}$ Classification by pesition (of the figure) only.

Exp. $\amalg_{c^{\prime}}$ Classification by position, but in a certain number of groups.

Exp. $\mathrm{II}_{d}$ Classification by figure only.

Exp. $\mathrm{II}_{a^{\prime}}$ Classification by figure, but in a certain number of groups.

Result: By comparison of the results in Exp. I with those in Exp. II of the same person, the crieria of classification in Exp. I was somewhat secured.

In Exp. $\mathrm{II}_{b}$ and Exp. $\mathrm{II}_{c}$ all subjects clas ified the cards in a most $\mathrm{t} \mathrm{e}$ same manner.

In Exp. $\mathrm{II}_{d}$ all subjects classified them in entirely different manners. Each classification in Exp. $\Pi_{b}, \Pi_{c}$ and $\Pi_{c}$ was guessed from that in Exp. $\mathrm{II}_{b^{\prime}}, \mathrm{I}_{c^{\prime}}$ and $\mathrm{II}_{a^{\prime}}$.

Experiment III Problem: It was aimed to decide whether each group in Exp. I (and II) had a definite criterium or not, and if so, then whe her 
it could be understood by other persons or not.

Method: The multip choice apparatus was used. (See Fig. II). The experimenter took one card out of the group that was to ke examined, and. mixed it with 6 cards taken at random out of the whole cards excepting those of that group (only 7 cards being placed on the apparatus). While 7 cards were placed on the apparatus by the subjects (different from those of Exp. I and II), each card corresponding to each button, the bell was connected secretly with the button which corresponded to the card which was to be examined. The subjects had to press the button till the bell rang, then one set came to the end. In the following sets they had to try as before till they found out the relation among the cards and rang the bell at once without failure consecutively to the last set of the gioup. Their behaviours, solution or not, showed strictly whether the meaning of that group was understood by them or not. Accordingly the "Merkmal" of their solution was regarded as the condition of meaning-formation of that group.

Result: Nearly all groups in Exp. I (and II) were clarified in this way. The criteria as follows: Sub. I Figure; Sub. II Colour and Figure; Sub. III Colour; Sub. IV not clarified; Sub. V first, Colour; second time, Position: Sub. VI Figure: Sub. VII Figure.

In detail: for instance Group 6 of Sub. I in Exp. I: The criterium was "Symmetry of the figures" and so on.

The groups of classification by colour were solved easily. Those by position were also solved easily. But those by figure were not always solved easily.

Experiment IV Problem: The same as in Exp. III. But the groups unclarified in Exp. III owing to such special conditions as the subjects rang the bell by memory, the number of cards being few and the same one repeated in 3 or 4 sets, ought to be clarified by other methods.

Method: The groups were put before the subjects (different from those of Exp. I and II). They were asked why the cards were so classifi d.

Result: For instance, Group I of Sub. VII in Exp. I (3 cards) "They consisted of thin curve lines, but a card seemed somewhat unfit." and so on.

Experiment $V$ Problem: It was aimed to examine whether the conditions found in Exp. III and IV were to be regarded as true ones or not.

Method: Subjects (different from those of Exp. I and II) were told to 
classify some cards (containing for instance, 3 groups, but mixed at random with each other) by the conditions (three kinds in this case) clarified in the preceeding experiments. If the results coincided with those in Exp. I, then those conditions shoud be true, if not, false.

Result: The objectively clarified conditions were all true. The classifications by 6 subjects out of 7 were thus all clarified.

But Sub. IV's was not understood by other subjects as well as by the experimenter. Even the classifications by other subjects accordnig to his own criteria differed very much among them as well as from his own in Exp. I. But he, afterwards, classified in the same manner as before. So his might be a special case.

Conclusion: The same object may have various meanings, but under the same conditions, it has always same meaning.

It is the characteristic feature of the "meaningless" figures that they can be classified in entirely different ways, i. e. may have various meanings. 